\title{
Does Intra-Disciplinary Historic Preservation Scholarship Address the Exigent Issues of Practice? Exploring the Character and Impact of Preservation Knowledge Production in Relation to Critical Heritage Studies, Equity, and Social Justice
}

\section{Content Analysis of Historic Preservation Scholarship}

Jeremy C. Wells

Associate Professor, University of Maryland, College Park (USA)

jcwells@umd.edu

\section{CONTEXT}

This paper is an expanded version of the content analysis that is summarized in my paper, "Does Intra-Disciplinary Historic Preservation Scholarship Address the Exigent Issues of Practice? Exploring the Character and Impact of Preservation Knowledge Production in Relation to Critical Heritage Studies, Equity, and Social Justice," that has been accepted for publication in the International Journal of Heritage Studies. Refer to this published paper for more complete details on this study.

\section{METHOD}

This content analysis was based on the analysis of paper, book, and edited book publications that were self-defined as contributing to preservation scholarship. The four primary objectives were to: 1) identify the authors of this group; 2 ) define what a "scholarly" publication is-only these publications were allowed to form the corpus of "preservation scholarship"; 3) collect every single "scholarly" publication produced by these authors, and 4) perform a content analysis on this preservation scholarship, dividing it into salient categories and themes.

In order to identify the authors of preservation scholarship, faculty were selected from National Council for Preservation Education (NCPE) member degree programs who were full-time and on the tenure-track or already tenured with a $50 \%$ or more teaching appointment in an historic preservation degree program (undergraduate or graduate).

Program web sites, emails, and phone calls to departments were used to identify full-time, tenure-track and tenured faculty with a $50 \%$ or more teaching appointment to an historic preservation program. Where departments did not share details on the distribution of faculty teaching responsibilities, the relevant college or university course schedule listing was consulted to identify which courses each preservation faculty member taught across several semesters. Programs housed in institutions that do not use the tenure system, such as Boston Architectural College, Pratt, and Savannah College of Art and Design, were not included. 
A "scholarly publication" means that the publisher of a piece of scholarship employs a peerreview process to vet and approve the publication of this work. Even though the Forum Journal, CRM Magazine, and publications by the Getty and the International Council on Monuments and Sites (ICOMOS) are not consistently peer-reviewed, scholarship published in these venues was, however, included as an exception. The reason is that these venues are frequently cited by preservation scholars and, as such, are often considered to represent quality scholarship; this assessment was therefore respected for this study. Only scholarship in English that was published up until December 31, 2018 was included. Lastly, these additional criteria were used to categorically exclude publications:

- the publication was published by a predatory or vanity press; ${ }^{1}$

- encyclopedia entries;

- student textbooks;

- opinion pieces, editorials, book and conference reviews; exhibition reviews; awards, obituaries, and eulogies;

- professional reports (i.e., gray literature);

- coffee table books (i.e., books that focus on visual rather than written content);

- book prefaces;

- books or other publications only held by one library (usually the home institution of the scholar).

The following methods were used to find preservation scholarship literature:

- curricula vitarum (CV), when available through the Internet; there were many errors in these documents, however, such as listing publications that were never published, or incorrect publication titles and publication years. In no situation were CVs relied upon alone without cross-referencing other sources;

- public citation tracking databases: Google scholar, Web of Science, and Scopus;

- library subscription databases: Academic Search Complete, Art Abstracts, Avery Index, RIBA Catalogue, Art and Archaeology Technical Abstracts (AATA) Online, Anthropological Index Online, Bibliographic Database of the Conservation Information Network (BCIN), Bibliography of the History of Art, Google Books, JSTOR, Project Muse, ProQuest Central, and WorldCat;

- academia.edu and researchgate.net accounts of preservation scholars, when present.

I prepared and used a code book to categorize the content in each publication. The development of codes was informed by dividing preservation practice into its four primary areas: regulatory and planning work, materials-based (architecture, materials conservation) documentation and intervention, site interpretation, and advocacy. I used a process in which I reviewed the totality of the scholarship and created initial codes that were particularly salient; where multiple themes overlapped, I selected a single code that was most relevant, based on the publication's content. I then started coding each publication, altering the code book as

\footnotetext{
${ }^{1}$ There are several reputable services on the Internet that identify predatory publishers, such as
} https://beallslist.net/, https://www2.cabells.com/blacklist, and https://predatoryjournals.com/. 
necessary, based on the inter-related themes in the scholarship. I repeated this process several times until a clear pattern emerged among a specific group of themes. An intercoder reliability check confirmed that the pattern was consistent.

\section{CODING PROCESS}

In total, the process described in the method section resulted in the collection of 530 publications that define the corpus of "intradisciplinary preservation scholarship." In order to visually characterize this corpus, I created a word cloud from the publication titles (figure 1). I purposefully omitted the expected words and phrases associated with "history," "historic," "heritage," "conservation," and "preservation" as they overwhelmed the cloud.

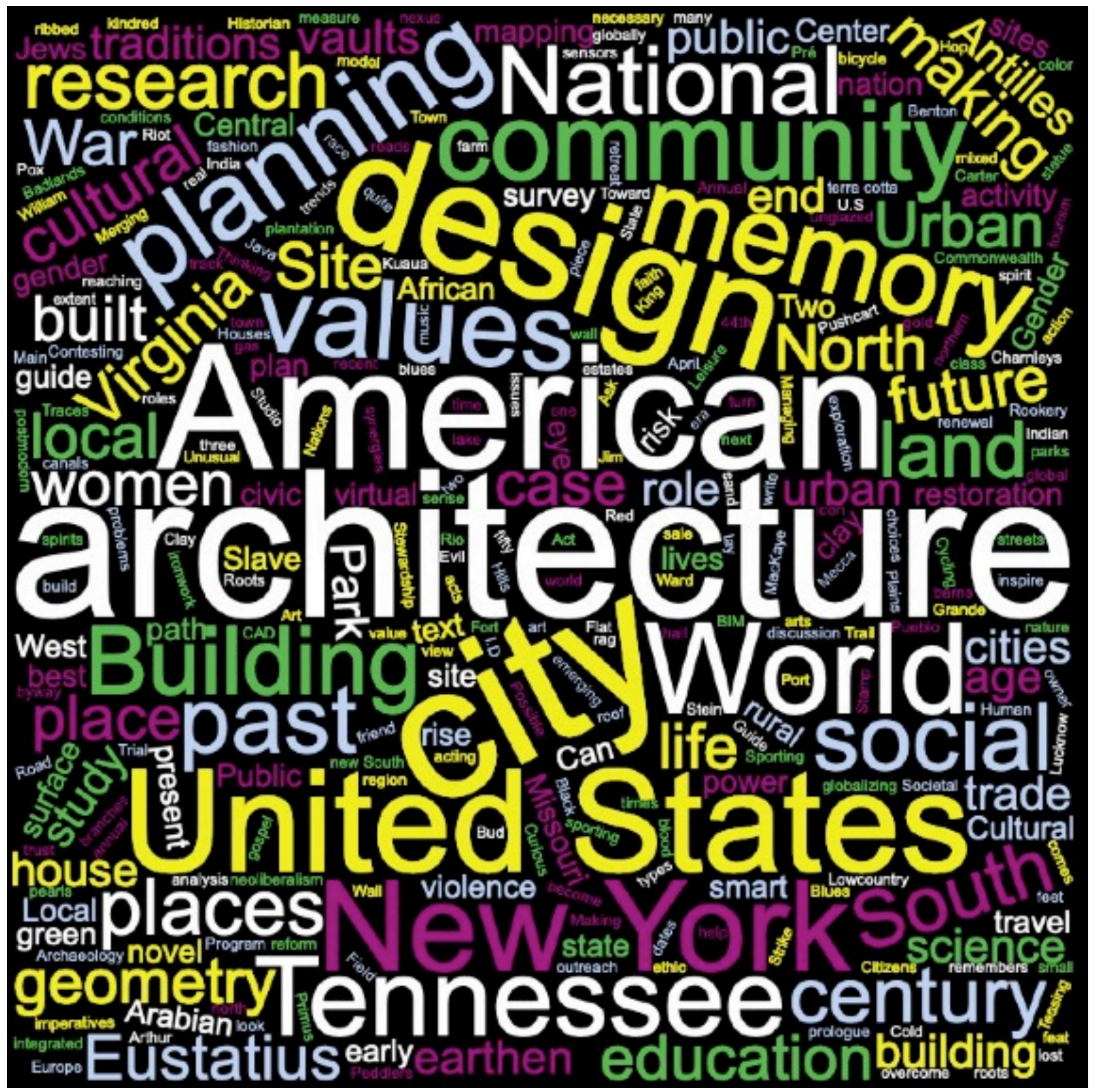

Figure 1. Word cloud of publication titles. 
Through an iterative coding process, three themes emerged, following by several sub-themes, which were as follows:

1. Topics that inform the preservation enterprise (TIPE): These are publications that might inform some aspect of historic preservation practice, but are not unique to the preservation enterprise; they are instead likely to be central to other disciplines. An example is an historical research paper on the biography of a doctor that could potentially inform why a place is historically significant, but could be equally applicable to a broad array of other fields, practices, or disciplines, such as medicine, chemistry, or museum studies.

2. Topics about the preservation enterprise (TAPE): These are publications that define, explore, and/or advocate for the orthodox scope, theory/philosophy, practice, or pedagogical approaches that are unique to the historic preservation field. Scholarship in this thematic area accepts and builds upon the dominant, orthodox approaches in the field, and as such, does not directly challenge the status quo. This topical area can be further subdivided into five additional sub-categories:

a. Characterization of the historic preservation field, including history and education;

b. Planning and policy, especially as they implemented through existing rules and regulations;

c. Materials conservation and preservation technology;

d. Orthodox preservation theory and philosophy that builds on centuries-old tradition;

e. Site management and interpretation.

3. Topics critical of the preservation enterprise (TCPE): These are publications that critically examine orthodox practice, including its doctrinal and regulatory assumptions. This scholarship is typically reflexive and most closely represents critical heritage studies in its overall approach.

a. Critical and reflective approaches;

b. Community engagement;

c. Social justice, equity, diversity, and inclusion.

Refer to figure 2 for a distribution of preservation scholarship categorized by these codes. 


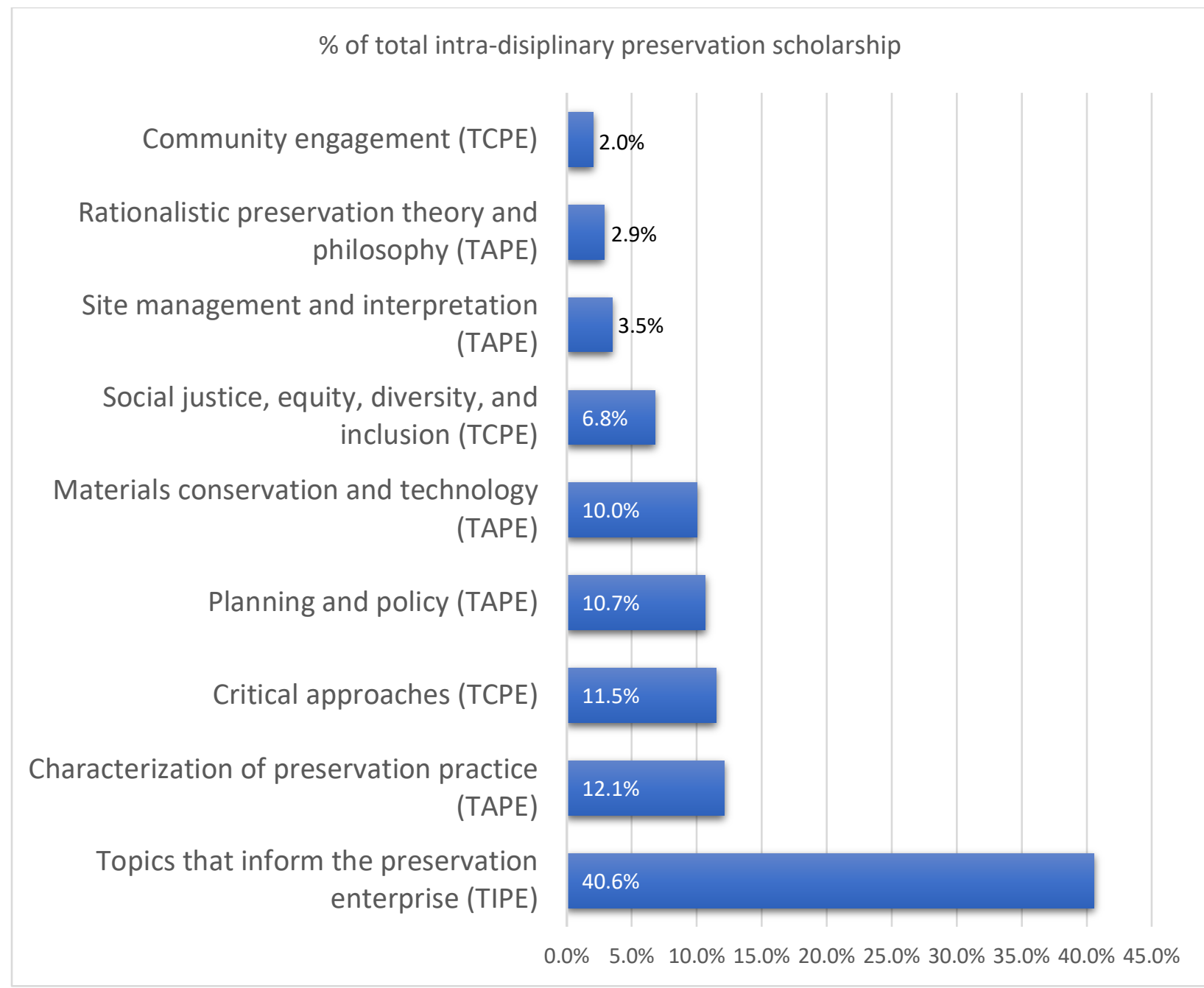

Figure 2. Overall distribution of intra-disciplinary preservation scholarship based on codes developed through content analysis, through December 31, 2018. Total number of publications represented is 488 (530 total publications minus 42 publications that have no relationship to historic preservation; see text). TIPE = Topics that Inform the Preservation Enterprise; TAPE = Topics About the Preservation Enterprise; TCPE = Topics Critical of the Preservation Enterprise; see text for details. 


\section{FINDINGS}

\section{TOPICS THAT INFORM THE PRESERVATION ENTERPRISE (TIPE)}

Almost half (40.4\%) of the refereed publications are TIPE literature; about three-quarters of these publications can be accurately characterized as positivistic history (i.e., a focus on objective facts and a singular interpretation that then emerges from these facts; conceptualizing history as broad patterns within a context of linear causation), although there are some notable exceptions, such as Max Page's (2001) proposal for a "radical public history" that represents a novel counter-argument against positivistic history. Themes that are appear most often by frequency include local history research in Montana, Tennessee, New York, Chicago, and the southeast; and contexts that address mining, political and labor history, transportation, class and gender, religious practice, colonial history, and urban transformation.

Geographically, there is an emphasis in preservation scholarship on local history in the western part of the United States, especially as relates to mining history (Clements, 1994, 1996, 2009, 2014), the rise and decline of western towns (Clements, 2002, 2003, 2011; Van West, 1993), and gambling and casinos (D. A. Smith \& Clements, 1997; Turdean, 2011). Carrol Van West is an especially prolific local historian, writing on the history of agriculture, development, healthcare, colonialism, monuments, and the significant men associated with these developments in Montana (1983b, 1985, 1986a, 1987b, 1987a, 1988b, 1990, 1993, 2004a) and Tennessee (1988a, 1994b, 1995, 1998, 2001, 2004b, 2016; Van West \& Binnicker, 2004).

The monumental and ordinary places of New York, Chicago, and Philadelphia are frequent topics. New York City is represented through the themes of parks, street merchants, tenements, builders, neglected islands, Broadway, Morningside Heights, the Garment District, and urban landscape change (Bluestone, 1987, 1991b, 1992; Dolkart, 1998, 2011, 2016b, 2016a, 2017; Mason, 2012; Mason et al., 2014; Page, 1999b, 2005) while the urban landscapes of Chicago, including the history of its skyscrapers are important themes (Bluestone, 1991a, 2004a, 2004b, 2013, 2017b). Philadelphia is represented through the architectural history of courthouses and power stations (Page, 1995; Wunsch \& Elliott, 2016).

Other TIPE literature focuses more specifically on social and cultural history, such as protests and political and labor movements, including the Vietnam and Civil Rights era (Rhodes, 1997, 2001, 2007, 2017); the Great Strike of 1877 (Hoffman, 2008), progressive era healthcare (Hoffman, 2001), and antebellum political movements (Van West, 1983a, 1983c). Class, gender, and work in the nineteenth century is well represented (M. R. Miller, 2003b, 2005, 2006b; M. R. Miller \& Benes, 2001; M. R. Miller \& Lanning, 1994). The historical social and cultural practice of Protestants and Jewish people are a dominant theme in TIPE literature (D. R. Miller \& Gilmore, 2016; M. R. Miller, 2009; Santoro, 2017; Stiefel, 2009, 2012, 2013, 2017b, 2018b; Stiefel \& Tesler-Mabé, 2016). Other authors focus on the broader historical social, cultural, and design dimensions of urban transformation (Appler, 2017a; Gilmore, 2006b; Hoffman, 2000; Holleran, 1990), with more specific foci on food markets, museums, courthouses, customhouses, state 
capitols, university campuses, and libraries (Bluestone, 1990a; Breisch, 2016, 2017; Donofrio, 2007, 2014, 2015; Kapp, 2018b; Page, 1995; Stiefel, 2015; Van West, 1989a; Vivian, 1999).

Themes more relevant to architectural history include the design and construction of skyscrapers (Bluestone, 2004a; Holleran, 1996; Page \& Conn, 1995), housing (Bricker, 2008, 2010), reinterpretations of the City Beautiful movement (Bluestone, 1988), southern plantation landscapes (Bluestone, 2012a; Brock \& Vivian, 2015; Graham et al., 2007, 2011; Vivian, 2018), neoclassicism (Semes, 2001b, 2001a, 2004, 2013a, 2015b), and the re-interpretation of ornament (Otero-Pailos, 2011).

TIPE scholarship on the history of construction materials, systems, and methods include the analysis of Spanish colonial building materials and techniques, such as vaulting and dome building (Ibarra-Sevilla, 2011, 2012, 2013b, 2013a, 2013c, 2014) and the use of mortars in fortifications (Wells, 2010b). Other, defined areas focus on discrete building units and finishes, such as sandstone (Matero \& Teutonico, 1982), brick (Broeksmit \& Sullivan, 2006), plain and decorative surface finishes (Matero, 1983, 1994; Silver et al., 1993), regional painting traditions (Matero \& Snodgrass, 1992), shotcrete (Sullivan, 2014), and hollow clay tile (Wells, 2007a). Lastly, a few authors have focused on engineering systems used in buildings, such as reinforced concrete (Donofrio \& Elliott, 2013) and technical aspects of Guastavino dome construction (Ibarra-Sevilla, 2015).

A few preservation scholars specialize in vernacular architecture; examples of this type of work that uses well-established methods from geography, social history, and architectural history is Tom Visser's (2012) analysis of American porches and Michael Tomlan's (2013) exposé on “hop culture." Literature in this area typically emphases rural building types over urban ones, such as barns and ranches (Visser, 1997; Vlahos, 2006) and company towns (Buckley, 1997), but urban contexts are also represented such as bicycle factories (McCullough, 2010, 2013, 2017). Seventeenth through nineteenth century cultural building practices in various areas of North America are also well represented (Breisch, 1994; Breisch \& Moore, 1986; van Den Hurk, 2005, 2006), but topics from the twentieth century are also present, such as how zoning ordinances impacted vernacular design (Visser, 1991), ordinary Americans' description of "architecture" and "landscape" (Conn \& Page, 2003), landscapes of prostitution (Bluestone, 2015), suburban developments (Hoffman, 1992, 2016), and gas station designs geared toward women (Donofrio, 2012a).

Closely related to vernacular architecture is literature that addresses cultural landscapes; the former topic often (but not always) focuses on specific building types, while cultural landscape research undertakes a more holistic focus on the entirety of the designed and natural environments. In particular, cultural landscape research can describe and analyze places without any "buildings" proper, such as roads, canals, and railroad and bike corridors (Bluestone, 1990b; Holleran \& Sanders, 2002; McCullough, 1998b, 2015; Spodek, 2002; Van West, 1986b, 1987d). Landscapes in which natural elements predominate are also a focus (Clements, 2014; McCullough, 1995, 1998a; McCullough et al., 2009; Page, 1999d) as are broad 
geographical areas defined by a singular theme, such as the Roosevelt's New Deal (Van West, 1994c).

Preservation scholarship often focuses on the historical importance of an individual-the quintessential famous, influential person who changed the world in some way. TIPE scholarship in this area over-emphasizes white males in deference to well-known women; minorities (such as African Americans) are not represented at all in this literature. Examples include white male architects (Breisch, 1997; Bricker, 1990, 2017; Brown, 1989, 2007; Chusid, 2017; Kapp \& Sanders, 2015; Otero-Pailos, 2000; Semes, 2017, 2018; Vivian, 2005), white male architectural critics (Breisch, 1992; Semes, 2014), white male planners (McCullough, 2012), and white male developers and business entrepreneurs (Dolkart, 2012; Hudgins, 2012; Rhodes, 2006, 2008; Van West, 1987c, 1994a, 2008a). The historical contributions of white women are limited to Rebecca Dickinson, Anne Frank, and Betsy Ross (M. R. Miller, 1998, 2002a, 2010a, 2014; Page, 1999c).

Often reliant on archaeological evidence, a number of authors explore the colonial culture of the American southeast (Brown, 2011; Hudgins, 1990, 1999, 2015; Marcoux, 2015; VanDerwarker et al., 2013). This TIPE literature, which is based on material culture theory and methods from processual archeology, uses an inductive process to understand the relationship that people had with cultural artifacts. Themes in this area of preservation scholarship mostly focus on Native American history and cultural practices (Marcoux, 2007, 2010a, 2010b, 2012a, 2012b; Marcoux et al., 2011; Marcoux \& Poplin, 2012; Marcoux \& Wilson, 2010). The excavation and interpretation of colonial-era artifacts in North America, including the Caribbean, is used to explain trade, conflicts, and dating methods (Gilmore, 2013; Gilmore \& Roth, 2013; Hatch et al., 2014; McMillan, 2016, 2017; McMillan et al., 2014; M. T. Smith et al., 2017). Material culture theory is also implicitly used by historians to understand the relationship that people have to specific objects. The advantage, compared to archaeology, is that historical records and oral history are used to help supplement the social and cultural practices related to these objects. Literature that addresses this theme includes various crafts (especially basketmaking) (Hurley et al., 2013; M. R. Miller, 2006a; Van West, 2004c), dressmaking (M. R. Miller, 1999, 2003a, 2003c, 2003d), and manufacturing (Clements, 1997).

\section{TOPICS ABOUT THE PRESERVATION ENTERPRISE (TAPE)}

\section{Materials conservation and preservation technology}

In TAPE literature, there are three main areas of research that directly address historic fabric in some fashion: documentation, materials conservation, and preservation technology. The documentation of the physical fabric of buildings involves metric survey, photography, and instrumental analyses. The conservation of architectural materials applies scientific methods from materials science and chemistry toward the analysis, repair/consolidation, and loss compensation of building fabric with an emphasis on authenticity. Lastly, preservation technology focuses on contemporary interventions to sustain the physical integrity of building fabric. 
There are a few publications on general topics related to materials conservation, including the conservation of entire sites (Bargues-Ballester et al., 2017; Gilberg \& Vivian, 2001; Matero, 1999; Matero et al., 1998, 2000; Weaver \& Matero, 1997), but a narrow focus on specific materials is more typical in TAPE literature. The largest area of TAPE scholarship in materials conservation addresses the global conservation of earthen construction materials, such as adobe, rammed earth, and puddled earth (Avrami et al., 2008, 2012, 2014; Matero, 1995, 2004, 2012, 2015; Matero \& Cancino, 2000). The cleaning of materials, which involves scientific testing and treatment with a goal of minimizing harm, focuses mostly on marble and terra cotta (Hall \& Matero, 2011; Matero, 1984; Matero et al., 2016; Matero \& Freese, 1978; Matero \& Tagle, 1994; Matero \& Teutonico, 1996). Literature on consolidation, in which the loss of existing, friable, disaggregated, and/or delaminated building fabric is mitigated through the application of a variety of "compatible" contemporary and traditional organic and inorganic materials, is well represented (Correia \& Matero, 2008; Ferron \& Matero, 2011a, 2011b; Jang \& Matero, 2018; Tudor et al., 1990); the use of various adhesives to reattached delaminated material, which is related to consolidation, addresses plaster materials (Hinchman et al., 2006; Matero \& Bass, 1995). The conservation of limestone is also represented in TAPE literature (Matero \& Siravo, 2004) along with mortar analyses and replication (Matero, 2001a, 2001b). Lastly, literature in this area provides potential solutions to protect archeological ruins (Avrami et al., 2002; Lim et al., 2013).

Other than a couple of general treatises (Leifeste, 2013; Young, 2008a), TAPE literature in preservation technology is mostly concerned with the stabilization of buildings, structures, and ruins (Jerome et al., 2003; Visser, 1993; Wells, 2003). Technology, however, features in much of the literature in documentation, chiefly the use of GIS (graphical information systems) and 3-D laser scanning (Christensen et al., 2016; Chusid \& Minner, 2016; Hallo et al., 2012; Jessica et al., 2011; Matero et al., 2003). Remote sensing technologies, such as infrared thermography, radar, and resistivity testing, are represented (Elisabetta \& Spodek, 2003; Gilmore, 2008; Spodek \& Rosina, 2009). Literature in this area also includes general site plans for condition surveys (Matero, 2003; Matero \& Peters, 2003), the identification of cultural resources (Livi Smith, 2017), and methods to preserve documentation records (Wells, 2006).

\section{Planning and policy}

Policy, as it applies to the preservation enterprise is broad, encompassing planning, law, economics, sustainability, and disaster planning, among other possibilities. While this area of TAPE scholarship may advocate for change, the context for these arguments are framed in a way that supports, rather than challenges, orthodox expert rule and top-down methods. Thus, while a policy paper might argue for including more properties on the US National Register of Historic Places (NR), it will not attempt to critique how NR criteria prevents such listings from happening in the first place. For example, a significant number of publications explore ways to increase the number of buildings and places listed on the NR (Appler, 2016a; Goetcheus, 2002; Holleran \& Chalana, 2006; McCullough, 2003; Vivian, 2016b) and how cities and countries could more fully participate in World Heritage processes (Ibarra-Sevilla, 2018; Reap, 2002, 2006; 
Stiefel, 2018c), including the use of social science methods to characterize the "spirit and feeling" of World Heritage properties (Wells, 2014a). None of these publications, however, explore the possibility that the foundational criteria and policies around the NR and World Heritage may, in themselves, be a significant factor in excluding many buildings and places for inclusion in these lists.

Preservation planning, on the local level, is well represented in TAPE literature with an emphasis on how preservation relates to economic development and place-making (Kapp, 2012; Kapp \& Armstrong, 2012; Mason, 2009a; D. A. Smith \& Clements, 1997; Wells, 2015c), and low-income housing (Spodek \& House, 2017). Other themes that relate to preservation planning include preservation economics (Bluestone et al., 1999; Mason, 1999a, 1999b, 2008a; Van West, 1996; Vivian et al., 2000; Vivian, 2016a) and preservation law (Draye \& Reap, 2008; Reap, 1979, 2005, 2011; Wells \& Lixinski, 2016, 2017). Three publications have also explored ways to help orthodox preservation practice proactively address issues related to natural and manmade disasters (Appler, 2016b; Avrami et al., 2017; Chabbi et al., 2014). A couple of publications focused on planning and policy issues within organizations and programs, such as the National Park Service (Whisnant \& Miller, 2016) and heritage areas (Crotts et al., 2002).

Sustainability is another theme that, based on the number of publications, is a significant part of TAPE literature. Some work in this area advocates for change in architectural and "green" building practices so that they incorporate more adaptive use and building preservation, using empirical evidence as a guide (Chusid, 2010a, 2016; Koziol, 2009; Young, 2008b, 2008c) while other authors explore the conservation of building fabric as an inherently sustainable activity from an environmental as well as a social perspective (Avrami, 2011; Matero \& Teutonico, 2003). A landscape-based approach to sustainability is also represented (McGehee et al., 2013). Literature in this area also critiques what is perceived to be over-emphasis on the environment, choosing, instead, to investigate social aspects of sustainability (Donofrio, 2012b); in particular, Erica Avrami (2009, 2010, 2016) advocates for important changes to preservation policies in order to make "preservation more sustainable" through an explicit social focus. Stiefel and Leifeste (2018), on the other hand, make an explicit call to environmental conservation by advocating for combining this field with historic preservation.

While most policy and management scholarship centers on US-based practice, Asia is also represented (especially India) (Krishna, 2013, 2014, 2016) along with the Netherland Antilles (Haviser \& Gilmore, 2011).

\section{Site management and interpretation}

Literature on site interpretation focuses on museums in general (Bryk et al., 2015; Livi Smith, 2011; Page, 1999a; Van West, 1989b), house museums (Bryk, 2002), religious sites (Stiefel, 2014d), archaeological sites (Matero, 2010), botanical gardens (Matero, 2005), and large, culturally-defined areas in the American southeast (Cook, 2016; Kapp, 2015); other publications explore more general concepts related to interpretation and tourism (Clements, 2005; Huang et al., 2014; Van West, 1996). Within most of these publications, there is an exploration of when 
pedagogical (fact-based) or experiential (feeling-based) approaches to interpretation are warranted and the appropriate use of technology. The literature in this area also focuses more explicitly on management practices, including those related to "toxic" sites, college campuses, Hadrian's Wall, and Port Arthur (Bluestone, 2007; Livi Smith \& Spencer, 2012; Mason, MacLean, et al., 2005; Mason, Myers, et al., 2005).

\section{Orthodox preservation theory and philosophy that builds on centuries-old tradition}

Orthodox preservation theory is an analysis of the conceptual basis for how and why practice is performed in a certain way and is grounded in long-established concepts in the field that have, in some cases, existed for many decades, if not centuries. Preservation philosophy is a broader search for generalizable principles across practice, but which still sanctions its ideas through orthodox theory. In both cases, these investigations are dependent on rationalistic (deductive, a priori) rather than empirical (inductive, a posteriori) reasoning. There is little orthodox preservation scholarship that attempts to add to or interpret long-accepted theory and philosophy established by nineteenth century authors (e.g., Ruskin, Boito) and twentiethcentury modernists (e.g., Carbonara, Philippot). There are a few exceptions, however.

Descriptive, historical explorations of orthodox preservation theory are represented in TAPE literature (Matero, 2013a). There are also applications of orthodox theory to interventions in building or archaeological fabric that impact authenticity, such as loss compensation (Matero, 2006a, 2007b), interpreting design intent (Matero \& FitzGerald, 2007), interpretation of archaeological sites (Matero, 2000b, 2006b), and placemaking (Matero, 2011; Preucel \& Matero, 2008). The aesthetic interpretation of historic places is also related to authenticity (Livi Smith, 2014a). In common with the nineteenth- and early twentieth-century literature on orthodox theory is a strong interest in ethics as applied to interventions in building fabric. For instance, there is a proper "ethical" stance toward building fabric of which a practitioner should be fully aware (Matero, 1993, 2013b). To be an ethical practitioner, one must make sure to adopt an interdisciplinary approach that combines the authority of the natural sciences and humanities (Matero, 2006b).

\section{Characterization of the historic preservation field, including history and education}

Literature that describes contemporary practice in the historic preservation field and its historical genesis also includes publications that address historic preservation education, primarily at the post-secondary level. Scholarship on these topics that take a critical, as opposed to a descriptive, approach has been included under the TCPE category.

A common tool to describe historic preservation is to characterize its practice through the lens of other disciplines, such as landscape architecture (Goetcheus et al., 2016) and architectural history (Bricker, 2004); to be sure, a cultural landscape lens is, by far, the most common way that the field is characterized in these publications (Goetcheus, 2008b; Goetcheus \& Mitchell, 2014; Mason, 2008b, 2010). The challenges of working in an inherently multidisciplinary field is explored (Wells, 2009) as is scholarship that investigates employment trends (Visser, 2009; 
Wells, 2018). Other scholarship advocates for the expansion of historic preservation practice by describing its orthodox activities (Page, 2016; Tomlan, 2015).

The trades-e.g., carpenters, masons, plasters - are essential for the restoration of historic buildings, but preservation scholars, with one exception, do not focus on this topic. Over the decades, there has been a significant loss in intangible heritage related to traditional techniques in building construction and repair. Paul Kapp's (Kapp, 2016, 2017; Kapp \& Crumpton, 2015) scholarship on the artisan economy and industrial heritage, however, is an exception to this rule and seeks to sustain the intangible heritage around the building trades.

Prior to 2000, there were only three publications that explored the history of the preservation field (Bluestone, 1994; Holleran, 1998; Tomlan, 1992), but since then, this area of preservation scholarship has expanded greatly, starting with Giving Preservation a History, edited by Max Page and Randall Mason (2004). Much like TIPE scholarship, there is a geographic focus on large cities, namely Boston (Holleran, 2004), New York City (Mason, 2004, 2009b), Chicago (Bluestone, 1998, 2004c, 2005), Richmond (Bluestone, 2012b), and Alexandria (Virginia) (Appler, 2015) although the broader scope of the United States is also represented (Bluestone, 2011). Two publications explore various preservation practice histories in the Indian cities of Lucknow and New Delhi (Chusid, 2015; Krishna, 2017).

Not all literature in the history of preservation practice is place-centric; a minority of publications look more at the instruments and institutions of practice. For instance, Christopher Koziol (2014) analyzes the evolution of the Venice Charter in practice while Wayde Brown (2018) explores the history of reconstructed monuments. Goetcheus, Mitchell, and Barrett (2018) conduct an historical analysis of how the values inherent to the U.S. National Park Service-a government agency fundamental to both preservation doctrine and policy in the United States-have changed over time.

Lastly, because preservation scholars also teach, there is a significant body of literature that intersects historic preservation practice with pedagogy. A few publications address the field of preservation holistically, in terms of characterization of program, pedagogy, and curriculum development (Kapp, 2018a; Livi Smith, 2012; Stiefel \& Wells, 2014; Wells \& Stiefel, 2014a, 2014b) as well as its history (Bluestone, 1999). Within the field of preservation, the National Council for Preservation Education (NCPE) represents most programs; Michael Tomlan's (2010) publication on the history of NCPE remains the only one on the subject. Most scholars, however, approach preservation education through the primary non-preservation discipline with which they identify, such as landscape architecture (Goetcheus, 2008a), architecture (Kapp, 2009; Kapp et al., 2014; Tomlan, 1994a), real estate development (Benedict \& Goetcheus, 2014b, 2014a), public history (M. R. Miller, 2004; Weyeneth \& Vivian, 2016), and material culture/historical archaeology (Hudgins \& Leifeste, 2017).

Preservation education scholarship focuses on the need for students to gain real-world experience, such as through service learning (Tomlan, 1998; Vlahos, 1998) and field-based experiences (Holleran \& Ibarra-Sevilla, 2017; Matero, 1997, 2007a; Tomlan, 1994b). Specific 
pedagogical techniques in teaching sustainability, stakeholder empathy, vocational trades, planning, archival research, and social science-based theses are represented in the literature as well (Chusid, 2010b; Cook \& Alderman, 2017; Livi Smith, 2014b; Stiefel, 2018a; Wells, 2014b).

\section{TOPICS CRITICAL OF THE PRESERVATION ENTERPRISE (TCPE)}

\section{Critical approaches that challenge orthodox historic preservation theory and practice}

Scholarship in this area can be broadly divided into rationalistic and empirical approaches. For instance, questioning whether the older built environment should be treated as if it is a museum instead of a socially dynamic place (Bluestone, 2016, 2017a), is clearly critical of orthodox assumptions while being based on rationalistic, deductive reasoning. Other authors in this category accept the authenticity premise of orthodox preservation doctrine, and use a rationalistic perspective to reject the implicit modernist design principles that buttress the supposed need to differentiate "new" from "old" building fabric. Steven Semes (2007, 2015a) advocates for a "recovery" of not only the traditional building trades, but also traditional (premodern) architectural design as a way to achieve "continuity" in urban landscapes. Semes (2009) claims that orthodox preservation doctrine has resulted in poor design that could have been avoided by paying closer attention to tradition; he uses several case studies of neotraditional design to further enforce this point (Semes, 2012, 2013b). Lauren Bricker (2009) makes similar claims about how the US Secretary of the Interior's Standards, as applied to local historic districts, results in poor design that stifles creativity.

Other authors use a rationalistic approach to provoke orthodox practice. Jorge Otero-Pailos has carved out a unique niche in preservation theory which he refers to as "experimental preservation" or "preservation art" (Otero-Pailos, 2016). Otero-Pailos's work (1998, 2009, 2015) challenges the status quo, and thus shares a goal common to critical heritage studies, but assumes an ontological construct more common to architectural and art criticism than critical heritage studies. While not reviewed in this paper, Otero-Pailos's artwork, which has been exhibited globally, is designed to provoke orthodox practice. Rem Koolhaas (2014), a wellknown international architect, has worked with Otero-Pailos to explore what would happen in a world where everything is "preserved" and urban change is fundamentally stymied. Of note is that experimental preservation has provoked criticism from other preservation scholars in terms of whether or not it is actually relevant to the pragmatic perspective of practice (Mason, 2018).

Preservation scholarship that uses empirically-based analyses to challenge orthodoxy is closely aligned to critical heritage studies, a relatively recent field of research that adopts critical theory, critical realism, constructivism, post-colonialism, and post-structuralism to characterize built heritage conservation practice through the AHD. While there is some concern as to whether or not critical heritage studies is adequately addressing the pragmatic, practice-based aspects of historic preservation (Wells, 2016a), critical heritage studies has become the dominant field that is questioning the status quo in historic preservation. Preservation scholarship that uses approaches that define critical heritage studies is largely empirical and 
usually informed by methods from anthropology, sociology, communication studies, environmental psychology, and urban planning.

While post-structuralist perspectives of heritage are well represented in critical heritage studies literature, there is only one example (Wells, 2007b) from a preservation scholar. Similarly, broader ontological critiques comparing, for instance, the empiricist-positivist paradigm dominant in practice against other paradigms, such as those that support action research, is only represented by a couple of publications (Wells, 2015a, 2017a). That does not mean, however, that other perspectives, critical of practice, are not present in the literature. To be sure, the grounded limitations of the narrow, positivist perspective on historical significance is represented (Stiles, 2010; Tomlan, 1997) as are ways that the "performance" of heritage conservation can be assessed using methods from environmental conservation (Wells, 2012). There is also an edited volume solely focused on pragmatic visions for critiquing practice with an eye to the future (Page \& Miller, 2016; Wells, 2016b).

A significant amount of critical preservation scholarship is concerned with heritage discourse and the development and destruction of rhetoric around built heritage, often incorporating extra-Western perspectives and employing the dualism of conventional experts/orthodox doctrine versus laypeople/situated knowledge. Examples of work in this area include critiques of policy (Koziol, 2007, 2008, 2012) and the negotiation of meanings in the creation of a specific heritage rhetoric in Western and non-Western contexts (Asif \& Rico, 2017; Lafrenz-Samuels \& Rico, 2015; Rico, 2015, 2017a, 2017b). More specifically, Trinidad Rico (Exell \& Rico, 2013, 2014; Rico, 2008, 2017c, 2017d, 2017e, 2017f), explores power structures in the control of heritage meanings through a colonial lens in the Arabian Peninsula including the fear of Islamic heritage by dominant global cultural groups (Rico, 2014a, 2014b), and the colonialism that is inherent in defining and planning for "heritage at risk" (Rico, 2014c, 2016a).

Other researchers address the cultural and psychological dimension of authenticity and its implications for practice, especially as it relates to design review (Wells, 2010a, 2010c, 2017b; Wells \& Baldwin, 2012). A "values-based" approach to preservation practice, which usually does not reference critical heritage studies literature, yet often shares its critical aims, has been present in preservation scholarship since 2000, largely through the efforts of preservation scholars Randy Mason and Erica Avrami (Avrami et al., 2000; Mason, 2002, 2003, 2006a, 2006b; Mason \& Avrami, 2002). Other preservation scholars critique practice through a "values" lens as well (Bluestone, 2000; Koziol, 2013; Rico, 2016b; Wells, 2015b; West et al., 2010).

Lastly, Avrami et al. (2018) present one of the only examples of an analysis of local historic preservation policy in the US that is critical of the field's lack of civic engagement, "complicit acceptance" of economics as the only viable indicator of success, and for promoting a system that fails to recognize a relationship between how properties are listed and the purported benefits of historic preservation. This analysis also found a disconnect between the values espoused by the public and in preservation policies: the public primarily emphasizes social values while preservation policy primarily emphasizes economic values. 


\section{Community engagement}

Preservation scholarship that specifically addresses applied community engagement is limited. Literature in this area discusses not only the need for this kind of grass-roots engagement, but also details on-the-ground methods to identify specific kinds/types of community groups based on their identity, affiliation, or some other kind of sociocultural characteristic. Community engagement scholarship also looks at ways data from this kind of research can or already has influenced grass-roots practice in some fashion. Most of the publications in this category detail public archaeology projects, with a focus on interactions with municipal (local) governments (Appler, 2012, 2013b, 2017b; Baugher et al., 2017a, 2017b). More general community engagement research focuses on crowdsourcing, community art, design review, and the involvement of citizens in survey projects (Melcher et al., 2017; Minner et al., 2015, 2018; Wells, 2017c).

\section{Social justice, equity, diversity, and inclusion}

The majority of scholarship in this category explores the history of marginalized groups, usually in context with the built environment; with some exceptions (e.g., Brabec \& Goetcheus, 2015), this literature does not directly address contemporary people's relationship with the heritage being examined, nor does it discuss preservation practice in relation to these groups. Examples include African American history (Ayers \& Nesbit, 2011; Brabec \& Goetcheus, 2015; Cook, 2016; Gilmore, 2006a; Goetcheus, 1999; Nesbit, 2013, 2014; Rhodes \& Jeffries, 2010; Van West, 2002, 2008b; Vivian, 2011), the history of Latinx peoples (Buckley \& Littmann, 2010), and Native American history (Heidemann \& Ligibel, 2017; Payne, 2011). The history of women, and especially African American women, is also represented (Cook \& Potter, 2018; M. R. Miller, 2002b, 2010b). Barry Stiefel's (2011, 2014a, 2014b, 2014c, 2016, 2017a; 2009) exploration of Jewish social and architectural history in relation to the built environment adds much to our understanding of the historical significance of synagogues and the places in which Jewish people lived.

Moving toward the present, some preservation scholars have specialized in the recognition and interpretation of "difficult sites" (also referred to as "sites of conscience"). This scholarship does address the present in terms of challenging orthodox practice's preference for overemphasizing places with positive aesthetic and historical attributes. Examples include advocacy to recognize and preserve "bad places" (Page, 2015), places of civil protest and state terrorism (Page, 2008, 2013), and places associated with the Holocaust (Cook \& Alderman, 2015; Cook \& van Riemsdijk, 2014) and World War I (Kapp \& Otnes, 2018). While not centered on difficult places, a couple of preservation scholars advocate for policy changes in relation to the history of marginalized groups. James Buckley's (Buckley, 2018; Buckley \& Graves, 2016) work centers on how planning policy can better recognize and conserve places historically associated with cultural groups and Carrol Van West (1997) advocates for better ways to make sure that built heritage associated with race, class, and gender can be used to nominate properties to the US National Register of Historic Places. 
Very little preservation scholarship, however, investigates the relationship of contemporary marginalized groups with their own built (or place-based) heritage, including the kinds of social justice and equity issues that arise within these contemporary communities when their heritage is sidelined by rules and regulations as well as orthodox discourse. Three exceptions are moving "beyond compliance" when preserving the heritage of Native American ancestral sites (Matero, 2000a), interpreting a local park to reflect the heritage of African American stakeholders (Appler, 2013a), and the way in which Latin Americans view the past and present of an historic streetscape in Allentown (Pennsylvania) (Wells et al., 2016).

\section{SCHOLARSHIP THAT HAS NO CLEAR RELEVANCE TO PRESERVATION}

A significant amount of scholarship produced by intra-disciplinary preservation scholars has little or no direct relationship to historic preservation and therefore was not included in the distribution analysis of "preservation scholarship" represented in figure 2 . This represents 42 publications on topics such as faculty involvement in higher education, electronic classrooms, postmodern architectural design, and historical atlases. 


\section{Bibliography of published scholarship that was included in this content analysis}

Appler, D. R. (2012). Municipal archaeology programs and the creation of community amenities. The Public Historian, 34(3), 40-67.

Appler, D. R. (2013a). Archaeology and sense of place in Alexandria, Virginia: An exploration of the changing significance of Fort Ward Park. In C. Niedt (Ed.), Social justice in diverse suburbs: History, politics, and prospects (pp. 172-184). Temple University Press.

Appler, D. R. (2013b). Tracing the roots of municipal archaeology in St Augustine, Florida: The story of how "the oldest city" connected archaeology, local government, and the public. Public Archaeology, 12(1), 7-26.

Appler, D. R. (2015). The formation of the Alexandria Archaeological Commission: Connecting citizen activism, archaeology, and local government in Alexandria, Virginia. Journal of Community Archaeology \& Heritage, 2(1), 22-39.

Appler, D. R. (2016a). Affordable housing in National Register districts: Recognizing the advantages of historic urban neighborhoods in Louisville and Covington, Kentucky, USA. Journal of Urbanism: International Research on Placemaking and Urban Sustainability, 9(3), 237-253.

Appler, D. R. (2016b). Building community resilience through historic preservation. Journal of the American Planning Association, 82(2), 92-103.

Appler, D. R. (2017a). Changing the scale of analysis for urban renewal research: Small cities, the state of Kentucky, and the 1974 Urban Renewal Directory. Journal of Planning History, 16(3), 200-221.

Appler, D. R. (2017b). Toward a theory of municipal archaeology: Why local government should become public archaeology's new best friend. In S. Baugher, D. R. Appler, \& W. Moss (Eds.), Urban archaeology, municipal government and local planning: Preserving heritage within the Commonwealth of Nations and the United States (pp. 183-202). Springer International Publishing.

Asif, H., \& Rico, T. (2017). The Buddha remains: Heritage transactions in Taxila, Pakistan. In T. Rico (Ed.), The making of Islamic heritage: Muslim pasts and heritage presents (pp. 109123). Palgrave Macmillan.

Avrami, E. (2009). Heritage, values, and sustainability. In A. Richmond \& A. Bracker (Eds.), Conservation: Principles, dilemmas and uncomfortable truths (pp. 177-183). Butterworth-Heinemann.

Avrami, E. (2010). Preservation and sustainability. CRM: The Journal of Heritage Stewardship, 7(2), 20-23.

Avrami, E. (2011). Earthen architecture, sustainability, and social justice. In L. Rainer, A. B. Rivera, \& D. Gandreau (Eds.), Terra 2008 Proceedings: 10th International Conference on the Study and Conservation of Earthen Architecture (pp. 328-331). Getty Conservation Institute.

Avrami, E. (2016). Making historic preservation sustainable. Journal of the American Planning Association, 82(2), 104-112.

Avrami, E., Allais, L., Amineddoleh, L. A., Gissen, D., Rush, L. W., \& Winter, T. (2017). Panel one: Prewar. From the 2016 Fitch Colloquium: Preservation and war. Future Anterior: Journal of Historic Preservation, History, Theory, and Criticism, 14(1), 1-4. 
Avrami, E., Barrow, J., Jerome, P. R., \& Taylor, M. R. (2002). Protective shelters for archaeological sites in the southwest USA A colloquium held at Tumacacori, Arizona, 912 January, 2001. Conservation and Management of Archaeological Sites, 5(1-2), 3-6.

Avrami, E., Guillaud, H., \& Hardy, M. (Eds.). (2008). Terra literature review: An overview of research in earthen architecture conservation. Getty Conservation Institute.

Avrami, E., Haney, G., \& Allen, J. (2012). New Gourna, in Egypt: Conservation and Community. In M. Correia, P. Jerome, M. Bondet, \& M. Achenza (Eds.), TERRA 2012: 12th SIACOT PROCEEDINGS - 11th International Conference on the Study and Conservation of Earthen Architectural Heritage 12th Iberian-American Seminar on Earthen Architecture and Construction. Argumentum.

Avrami, E., Haney, G., \& Allen, J. (2014). New Gourna: Conservation and community. Traditional Dwellings and Settlements Review, 26(1), 85.

Avrami, E., Leo, C.-N., \& Sanchez, A. S. (2018). Confronting exclusion: Redefining the intended outcomes of historic preservation. Change Over Time: International Journal of Conservation and the Built Environment, 8(1), 102-120.

Avrami, E., Mason, R. F., \& de la Torre, M. (2000). Values and heritage conservation. Getty Conservation Institute.

Ayers, E. L., \& Nesbit, S. (2011). Seeing emancipation: Scale and freedom in the American South. The Journal of the Civil War Era, 1(1), 3-24.

Bargues-Ballester, C., Whitaker, W., \& Matero, F. G. (2017). George Nakashima's Arts Building and Cloister: A conservation and management plan. APT Bulletin: Journal of Preservation Technology, 48(2/3), 67-74.

Baugher, S., Appler, D. R., \& Moss, W. (2017a). Introduction: Thinking globally and acting locally-Exploring the relationships between community, archaeological heritage, and local government. In S. Baugher, D. R. Appler, \& W. Moss (Eds.), Urban archaeology, municipal government and local planning: Preserving heritage within the Commonwealth of Nations and the United States (pp. 1-16). Springer International Publishing.

Baugher, S., Appler, D. R., \& Moss, W. (Eds.). (2017b). Urban archaeology, municipal government and local planning: Preserving heritage within the Commonwealth of Nations and the United States. Springer International Publishing.

Benedict, R., \& Goetcheus, C. L. (2014a). The critical role of preservation in graduate real estate curricula. In B. L. Stiefel \& J. C. Wells (Eds.), Preservation education: Sharing best practices and finding common ground (pp. 227-244). University Press of New England.

Benedict, R., \& Goetcheus, C. L. (2014b). The historic preservation gap in graduate real estate curricula. Journal of Real Estate Practice and Education, 17(2), 111-124.

Bluestone, D. (1987). From promenade to park: The gregarious origins of Brooklyn's park movement. American Quarterly, 39(4), 529-550.

Bluestone, D. (1988). Detroit's City Beautiful and the problem of commerce. Journal of the Society of Architectural Historians, 47(3), 245-262.

Bluestone, D. (1990a). Civic and aesthetic reserve: Ammi Burnham Young's 1850s Federal Customhouse designs. Winterthur Portfolio, 25(2/3), 131-156.

Bluestone, D. (1990b). Roadside blight and the reform of commercial architecture (J. Jennings, Ed.; pp. 170-184). lowa State University Press. 
Bluestone, D. (1991a). Constructing Chicago. Yale University Press.

Bluestone, D. (1991b). "The pushcart evil": Peddlers, merchants and New York City's streets, 1890-1940. Journal of Urban History, 18(1), 68-92.

Bluestone, D. (1992). "The Pushcart Evil": Peddlers, merchants and New York City's streets, 1890-1940. In D. Ward \& O. Zunz (Eds.), The Landscape of Modernity: New York City's Built Environment 1900-1940. Sage Foundation.

Bluestone, D. (1994). Preservation and renewal in post-World War II Chicago. Journal of Architectural Education, 47(4), 210-223.

Bluestone, D. (1998). Chicago's Mecca Flat blues. Journal of the Society of Architectural Historians, 57(4), 382-403.

Bluestone, D. (1999). Academics in tennis shoes: Historic preservation and the academy. Journal of the Society of Architectural Historians, 58(3), 300-307.

Bluestone, D. (2000). Challenges for heritage conservation and the role of research on values (E. Avrami, R. F. Mason, \& M. de la Torre, Eds.; pp. 65-67). J. Paul Getty Trust.

Bluestone, D. (2004a). 'A city under one roof,' Chicago skyscrapers, 1880-1895. In K. L. Eggener (Ed.), American Architectural History: A Contemporary Reader (pp. 177-205). Routledge.

Bluestone, D. (2004b). Charnleys by the lake: Houses, apartments and fashion on Chicago's Gold Coast. In R. Longstreth (Ed.), The Charnley House Louis Sullivan, Frank Lloyd Wright, and the Making of Chicago's Gold Coast (pp. 37-69). The University of Chicago Press.

Bluestone, D. (2004c). Chicago's Mecca Flat blues. In M. Page \& R. F. Mason (Eds.), Giving preservation a history: Essays on the history of historic preservation in the United States (pp. 201-256). Routledge.

Bluestone, D. (2005). Preservation and renewal in post-World War II Chicago. In C. Waldheim \& K. R. Ray (Eds.), Chicago architecture: Histories, revisions, alternatives (pp. 61-81). University of Chicago Press.

Bluestone, D. (2007). Toxic sites as places of culture and memory: Adaptive management for citizenship. In G. Macey \& J. Cannon (Eds.), Reclaiming the land: Rethinking superfund institutions, methods, and practices. Springer.

Bluestone, D. (2011). Buildings, landscapes and memory: Case studies in historic preservation. W. W. Norton.

Bluestone, D. (2012a). A.J. Davis's Belmead: Picturesque aesthetics in the land of slavery. Journal of the Society of Architectural Historians, 71(2), 145-167.

Bluestone, D. (2012b). Tobacco Row: Heritage, environment, and adaptive reuse in Richmond, Virginia. Change Over Time: International Journal of Conservation and the Built Environment, 2(2), 132-154.

Bluestone, D. (2013). Louis H. Sullivan's Chicago: From 'shirt-front,' to alley, to 'all-around structures'. Winterthur Portfolio, 47(1), 1-33.

Bluestone, D. (2015). Charlottesville's landscape of prostitution, 1880-1950. Buildings and Landscapes: Journal of the Vernacular Architecture Forum, 22(2), 36-61.

Bluestone, D. (2016). Dislodging the curatorial. In M. Page \& M. R. Miller (Eds.), Bending the future: Fifty ideas for the next fifty years of historic preservation in the United States (pp. 53-56). University of Massachusetts Press.

Bluestone, D. (2017a). Conservation's curatorial conundrum. Change Over Time, 7(2), 234-251. 
Bluestone, D. (2017b). Framing landscape while building density: Chicago courtyard apartments, 1891-1929. Journal of the Society of Architectural Historians, 76(4), 506531.

Bluestone, D., Klamer, A., Throsby, D., \& Mason, R. (1999). The economics of heritage conservation: A discussion. In M. de la Torre \& R. F. Mason (Eds.), Economics and heritage conservation: A meeting organized by the Getty Conservation Institute, December 1998 (pp. 19-22). The J. Paul Getty Trust.

Brabec, E., \& Goetcheus, C. L. (2015). The interrelationships of land, culture and heritage: The Gullah Geechee communities of the Southeastern United States. In K. Taylor, A. St. Clair, \& N. J. Mitchell (Eds.), Conserving cultural landscapes: Challenges and new directions (pp. 109-128). Routledge.

Breisch, K. A. (1992). Rome through the veil of time: Parker, Ruskin, and the romantic vision of classicism. Visual Resources: An International Journal on Images and Their Uses, 8(4), 335-342.

Breisch, K. A. (1994). Good building stone and a "lay of the land" that makes a "hominess": Norwegian-American settlement patterns and architecture in Bosque County, Texas. In M. J. Nelson (Ed.), Material culture and people's art among the Norwegians in America (pp. 92-117). The Norwegian American Historical Association.

Breisch, K. A. (1997). Henry Hobson Richardson and the small public library in America: A study in typology. MIT Press.

Breisch, K. A. (2016). The Los Angeles Central Library: Building an architectural icon, 1872-1933. The Getty Research Institute.

Breisch, K. A. (2017). American libraries 1730-1950. W.W. Norton \& Company.

Breisch, K. A., \& Moore, D. (1986). The Norwegian rock houses of Bosque County, Texas: Some observations on a nineteenth-century vernacular building type. Perspectives in Vernacular Architecture, 2, 64-71.

Bricker, L. W. (1990). The writings of Fiske Kimball: A synthesis of architectural history and practice. Studies in the History of Art, 35, 215-235.

Bricker, L. W. (2004). History in motion: A glance at historic preservation in California. Future Anterior: Journal of Historic Preservation, History, Theory, and Criticism, 1(2), 4-13.

Bricker, L. W. (2008). The Mediterranean house in America. Abrams.

Bricker, L. W. (2009). California's historic districts: Preservation in a vacuum. In D. Ames \& R. Wagner (Eds.), Design \& historic preservation: The challenge of compatibility (p. 61). University of Delaware Press.

Bricker, L. W. (2010). Western pragmatists and the modern American house. Southern California Quarterly, 91(4), 413-427.

Bricker, L. W. (2017). Architect O'Neil Ford's exploration of the solar house in Texas. APT Bulletin: Journal of Preservation Technology, 48(2/3), 21-28.

Brock, J., \& Vivian, D. J. (Eds.). (2015). Leisure, plantations, and the making of a new South: The sporting plantations of the South Carolina Lowcountry and Red Hills region, 1900-1940. Lexington Books.

Broeksmit, S. B., \& Sullivan, A. T. (2006). Dry-press brick: A nineteenth-century innovation in building technology. APT Bulletin: The Journal of Preservation Technology, 37(1), 45-52. 
Brown, W. (1989). Modernism and regionalism: Influences on the work of Leslie Fairn. Bulletin: Society for the Study of Architecture in Canada, 14(1), 14-18.

Brown, W. (2007). Percy Nobbs and the memorial garden at Grand Pré. Journal of the Society for the Study of Architecture in Canada, 32(2), 29-38.

Brown, W. (2011). "Left-behind" places of memory: The pattern of Grand Pré and New Echota. In D. Glenn, E. Bouvet, \& S. Floriani (Eds.), Imagining home: Migrants and the search for a new belonging (pp. 31-45). Wakefield Press.

Brown, W. (2018). Reconstructing historic landmarks: Fabrication, negotiation, and the past. Routledge.

Bryk, N. E. V. (2002). "I wish you could take a peek at us at the present moment": Infusing the historic house with characters and activity (J. F. Donnelly, Ed.; pp. 144-167). AltaMira Press.

Bryk, N. E. V., Hernandez, A., \& Stout, C. (2015). Old meets new: Technology and the visitor experience in the Lyons Country Store. In J. Decker (Ed.), Technology and digital Initiatives: Innovative approaches for museums (pp. 69-76). Rowman \& Littlefield.

Buckley, J. M. (1997). The factory without a roof: The company town in the redwood lumber industry. Perspectives in Vernacular Architecture, 7, 75-92.

Buckley, J. M. (2018). People in place: Local planning to preserve diverse cultures. In A. M. Labrador \& N. A. Silberman (Eds.), Oxford handbook of public heritage theory and practice (pp. 295-308). Oxford University Press.

Buckley, J. M., \& Graves, D. (2016). Tangible benefits from intangible resources: Using social and cultural history to plan neighborhood futures. Journal of the American Planning Association, 82(2), 152-166.

Buckley, J. M., \& Littmann, W. (2010). Latino landscapes in California's Central Valley. Buildings \& Landscapes: Journal of the Vernacular Architecture Forum, 17(2), 1-12.

Chabbi, A., Jerome, P., Jigyasu, R., Kelley, S. J., \& Reap, J. K. (Eds.). (2014). Tangible risks, intangible opportunities: Long-term risk preparedness and responses for threats to cultural heritage: Proceedings of the ICOMOS scientific symposium, 31 October 2012, Beijing, China. ICOMOS International Secretariat.

Christensen, P. H., Mcllhatton, D., Blair, N., \& Bonney, C. G. (2016). Multi-purpose 3-D real estate: Understanding the role of 3-D technology for enhancing resilience. Journal of Real Estate Literature, 24(2), 453-472.

Chusid, J. M. (2010a). Natural allies: Historic preservation and sustainable design (S. A. Moore, Ed.; pp. 170-186). Routledge.

Chusid, J. M. (2010b). Teaching sustainability to preservation students. APT Bulletin, 41(1), 4349.

Chusid, J. M. (2015). The India International Centre of Joseph Allen Stein: A story of cold war politics and the preservation of a modern monument. Journal of Architectural Conservation, 21(2), 71-84.

Chusid, J. M. (2016). Cautious engagement: Historic preservation and sustainable design. In S. A. Moore (Ed.), Pragmatic sustainability: Dispositions for critical adaptation (2nd ed) (pp. 155-168). Routledge.

Chusid, J. M. (2017). Joseph Allen Stein's experiments in concrete in the U.S. and India. APT Bulletin: Journal of Preservation Technology, 48(1), 23-31. 
Chusid, J. M., \& Minner, J. (2016). Time, architecture, and geography: Modelling the past and future of cultural landscapes. APT Bulletin, 46(2), 49-58.

Clements, E. L. (1994). Mining health and safety reform in Arizona 1901-1921. Mining History Journal, 1, 63-72.

Clements, E. L. (1996). Bust and bust in the mining West. Journal of the West, 35, 40-53.

Clements, E. L. (1997). Stamp mills and milling. In J. Engfer \& M. Roberts (Eds.), International symposium on mining (circa 1850-2000 and beyond): Proceedings publication (pp. 8798). Festival Fairbanks.

Clements, E. L. (2002). Black Hawk's jackpot decade: A metamorphosis in three acts. Journal of the West, 41, 59-70.

Clements, E. L. (2003). After the boom in Tombstone and Jerome, Arizona: Decline in western resource towns. University of Nevada Press.

Clements, E. L. (2005). For sale by owner: Western tourism and historic preservation. In A. Gulliford (Ed.), Preserving Western History (pp. 341-347). University of New Mexico Press.

Clements, E. L. (2009). Pragmatic revolutionaries?: Tactics, ideologies, and the Western Federation of Miners in the Progressive Era. Western Historical Quarterly, 40(4), 445467.

Clements, E. L. (2011). Rails to the Rockies: How Denver got two railroads (sort of), but not the one It really wanted. Colorado History (Denver Inside and Out) University Press of Colorado, 16, 3-9.

Clements, E. L. (2014). Forgotten ghosts of the southern Colorado coal fields: A photo essay. Mining History Journal, 21, 84-95.

Conn, S., \& Page, M. (Eds.). (2003). Building the nation: Americans write about their architecture, their cities, and their landscape. University of Pennsylvania Press.

Cook, M. R. (2016). Counter-narratives of slavery in the Deep South: The politics of empathy along and beyond River Road. Journal of Heritage Tourism, 11(3), 290-308.

Cook, M. R., \& Alderman, D. H. (2015). Public memory and empathy in Gunter Demnig's Stolpersteine project. In N. Rupprecht \& W. Koenig (Eds.), Global perspectives on the Holocaust: History, identity and legacy (pp. 321-348). Cambridge Scholars Publishing.

Cook, M. R., \& Alderman, D. H. (2017). Classroom as memory workspace: The educational and empathetic potentials of Twelve Years a Slave and Ask a Slave. In J. Stoddard, A. Marcus, \& D. Hicks (Eds.), Teaching difficult history through film (pp. 160-177). Routledge.

Cook, M. R., \& Potter, A. E. (2018). Unfinished geographies: Women's roles in shaping Black historical counter narratives. In H. Muzaini \& C. Minca (Eds.), After heritage: Critical perspectives on heritage from below (pp. 107-129). Edward Elgar.

Cook, M. R., \& van Riemsdijk, M. (2014). Agents of memorialization: Gunter Demnig's Stolpersteine and the individual (re-)creation of a Holocaust landscape in Berlin. Journal of Historical Geography, 43(1), 138-147.

Correia, J., \& Matero, F. G. (2008). Calcium tartrate tetrahydrate preconsolidation of saltcontaminated limestone at Mission San José Y San Miguel De Aguayo. Journal of the American Institute for Conservation, 47(2), 81-95.

Crotts, J. C., Muldrow, R. C., \& Rudd, H. F. (2002). Organisational needs and priorities of heritage areas in the USA. International Journal of Heritage Studies, 8(4), 337-348. 
Dolkart, A. S. (1998). Morningside Heights: A history of its architecture and development. Columbia University Press.

Dolkart, A. S. (2011). The fabric of New York City's Garment District: Architecture and development in an urban cultural landscape. Buildings \& Landscapes: Journal of the Vernacular Architecture Forum, 18(1), 14-42.

Dolkart, A. S. (2012). From the rag trade to riches: Abraham E. Lefcourt and the development of New York's Garment District. In R. Kobrin (Ed.), Chosen Capital: The Jewish encounter with American capitalism (pp. 62-92). Rutgers University Press.

Dolkart, A. S. (2016a). City and suburban homes company. In N. D. Bloom \& M. G. Lasner (Eds.), Affordable housing in New York: The people, places, and policies that transformed a city (pp. 48-51). Princeton University Press.

Dolkart, A. S. (2016b). Tenements. In N. D. Bloom \& M. G. Lasner (Eds.), Affordable housing in New York: The people, places, and policies that transformed a city (pp. 45-47). Princeton University Press.

Dolkart, A. S. (2017). Biography of a tenement house in New York City: An architectural history of 97 Orchard Street. University of Virginia Press.

Donofrio, G. A. (2007). Feeding the city. Gastronomica, 7(4), 30-41.

Donofrio, G. A. (2012a). Gender realignment: The design and marketing of gas stations for women. In H. Berghoff, U. Spiekermann, \& P. Scranton (Eds.), The rise of marketing and market research (pp. 237-267). Palgrave Macmillan.

Donofrio, G. A. (2012b). Preservation by adaptation: Is It sustainable? Change Over Time: International Journal of Conservation and the Built Environment, 2(2), 106-131.

Donofrio, G. A. (2014). Attacking distribution: Obsolescence and efficiency of food markets in the age of urban renewal. Journal of Planning History, 13(2), 136-159.

Donofrio, G. A. (2015). Feeding the city. In A. Berrizbeitia (Ed.), Urban landscape: Critical concepts in built environment (pp. 270-287). Routledge.

Donofrio, G. A., \& Elliott, M. (2013). Understanding the "world's largest" all-reinforced-concrete office building. APT Bulletin: Journal of Preservation Technology, 44(2/3), 23-33.

Draye, A. M., \& Reap, J. K. (2008). The protection of the archaeological heritage: The United States and Belgium compared. In B. Demarsin, E. J. H. Schrage, \& B. Tilleman (Eds.), Art \& law (pp. 322-338). Die Keure.

Elisabetta, R., \& Spodek, J. C. (2003). Using infrared thermography to detect moisture in historic masonry: A case study in Indiana. APT Bulletin: Journal of Preservation Technology, 34(1), 11-16.

Exell, K., \& Rico, T. (2013). 'There is no heritage in Qatar': Orientalism, colonialism and other problematic histories. World Archaeology, 45(4), 670-685.

Exell, K., \& Rico, T. (Eds.). (2014). Cultural heritage in the Arabian Peninsula: Debates, discourses and practices. Ashgate.

Ferron, A., \& Matero, F. G. (2011a). A comparative study of ethyl-silicate-based consolidants on earthen finishes. Journal of the American Institute for Conservation, 50(1), 49-72.

Ferron, A., \& Matero, F. G. (2011b). The consolidation of earthen surface finishes: Developing a protocol for treatment evaluation at Mesa Verde National Park. In L. Rainer, A. B. Rivera, \& D. Gandreau (Eds.), Terra 2008: The 10th international conference on the study and 
conservation of earthen architectural heritage (pp. 214-221). Getty Conservation Institute.

Gilberg, M., \& Vivian, D. J. (2001). The rise of conservation science in archaeology, 1830-1930. In A. Oddy \& S. Smith (Eds.), British Museum occasional papers series No. 145: Past practice-Future prospects: Conservation conference September 2001 (pp. 87-93). British Museum.

Gilmore, R. G., III. (2006a). All the documents are destroyed!: Documenting slavery for St Eustatius, Netherlands Antilles. In J. B. Haviser \& K. C. MacDonald (Eds.), African regenesis: Confronting social issues in the diaspora (pp. 70-89). Left Coast Press.

Gilmore, R. G., III. (2006b). Urban transformation and upheaval in the West Indies: The case of Oranjestad, St. Eustatius, Netherlands Antilles. In A. G. Green \& R. Leech (Eds.), Cities in the world, 1500-2000: Papers given at the conference of the Society for Post-Medieval Archaeology, April 2002 (pp. 83-95). Maney Publishing.

Gilmore, R. G., III. (2008). Geophysics and volcanic Islands: Resistivity and gradiometry on St. Eustatius. In B. Reid (Ed.), Archaeology and geoinformatics: Case studies from the Caribbean (pp. 170-183). University of Alabama Press.

Gilmore, R. G., III. (2013). St. Eustatius: The nexus for colonial Caribbean capitalism. In D. C. Comer (Ed.), The archaeology of interdependence: European involvement in the development of a sovereign United States (pp. 41-60). Springer.

Gilmore, R. G., III, \& Roth, M. J. (2013). Fort Oranje on St. Eustatius ca. 1755. FORT: The International Journal of Fortifications and Military Architecture, 41, 76-91.

Goetcheus, C. L. (1999). Booker T. Washington-The man and his landscape. CRM: Cultural Resource Management, 22(8), 31-33.

Goetcheus, C. L. (2002). Cultural landscapes and the National Register. CRM: Cultural Resource Management, 25(1), 24, 25.

Goetcheus, C. L. (2008a). Landscape preservation education in the United States: Status in 2007. Preservation Education and Research, 1, 15-28.

Goetcheus, C. L. (2008b). What's Next for Historic Landscape Preservation? In C. L. Goetcheus \& E. MacDonald (Eds.), Exploring the boundaries of historic landscape preservation: Proceedings of the twenty-ninth annual meeting of the Alliance for Historic Landscape Preservation 2007 Athens, Georgia (pp. 192-202). Clemson University.

Goetcheus, C. L., Karson, R., \& Park, E. (2016). Designing living landscapes: Cultural landscapes as landscape architecture. Landscape Journal: Design, Planning, and Management of the Land, 35(2), vi-xv.

Goetcheus, C. L., \& Mitchell, N. (2014). The Venice Charter and cultural landscapes: Evolution of heritage concepts and conservation over time. Change Over Time: International Journal of Conservation and the Built Environment, 4(2), 338-357.

Goetcheus, C. L., Mitchell, N. J., \& Barrett, B. (2018). Evolving values and how they have shaped the United States National Park System. Built Heritage, 3(2), 28-38.

Graham, W., Hudgins, C. L., Lounsbury, C. R., Neiman, F. D., \& Whittenburg, J. P. (2007). Adaptation and innovation: Archaeological and architectural perspectives on the seventeenth-century Chesapeake. The William and Mary Quarterly, 64(3), 451-522.

Graham, W., Hudgins, C. L., Lounsbury, C. R., Neiman, F. D., \& Whittenburg, J. P. (2011). Adaptation and innovation: Archaeological and architectural perspectives on the 
seventeenth-century Chesapeake. In C. R. Lounsbury (Ed.), Essays in early American architectural history: A view from the Chesapeake (pp. 33-74). University of Virginia Press.

Hall, L. R., \& Matero, F. G. (2011). Considerations on complex sequential treatments of gypsum crusts: The Carrara marble capitals of the Philadelphia Merchants' Exchange. Journal of the American Institute for Conservation, 50(2), 123-148.

Hallo, J. C., Beeco, J. A., Goetcheus, C. L., McGee, J., McGehee, N. G., \& Norman, W. C. (2012). GPS as a method for assessing spatial and temporal use distributions of nature-based tourists. Journal of Travel Research, 51(5), 591-606.

Hatch, D. B., Heath, B. J., \& McMillan, L. K. (2014). Reassessing the Hallowes Site: Conflict and settlement in the seventeenth-sentury Potomac Valley. Historical Archaeology, 48(4), 46-75.

Haviser, J. B., \& Gilmore, R. G., III. (2011). Netherlands Antilles. In P. E. Siegel \& E. Righter (Eds.), Protecting heritage in the Caribbean (pp. 134-142). University of Alabama Press.

Heidemann, M. A., \& Ligibel, T. J. (2017). Preserving and interpreting a shared mission: Peter Dougherty, Chief Ahgosa, and northern Michigan's Old Mission. Michigan Historical Review, 43(1), 29-56.

Hinchman, J., Matero, F. G., \& Radin, A. (2006). Performance of injection adhesives for the Great Hall Ceiling at Drayton Hall, Charleston. APT Bulletin: The Journal of Preservation Technology, 37(2/3), 47-58.

Hoffman, S. J. (1992). "A plan of quality": The development of Mt. Lebanon, a 1920s automobile suburb. Journal of Urban History, 18(2), 141-181.

Hoffman, S. J. (2000). The decline of the Port of Richmond: The Richmond Chamber of Commerce and the U.S. Army Corps. Of Engineers. The Virginia Magazine of History and Biography, 108(3), 255-278.

Hoffman, S. J. (2001). Progressive public health administration in the Jim Crow South: A case study of Richmond, Virginia, 1907-1920. Journal of Social History, 35(1), 177-194.

Hoffman, S. J. (2008). Looking north: A mid-south perspective on the Great Strike. In D. O. Stowell, (Ed.), The great strikes of 1877 (pp. 105-135). University of Illinois Press.

Hoffman, S. J. (2016). Community building comes south: The development of Gentilly Terrace, "where homes are built on hills." Louisiana History: The Journal of the Louisiana Historical Association, 57(3), 323-348.

Holleran, M. (1990). Filling the Providence Cove: Image in the evolution of Urban Form. Rhode Island History, 48(3), 65-85.

Holleran, M. (1996). Boston's "sacred sky line": From prohibiting to sculpting skyscrapers, 18911928. Journal of Urban History, 22(5), 552-585.

Holleran, M. (1998). Boston's "Changeful times": Origins of preservation \& planning in America. Johns Hopkins University Press.

Holleran, M. (2004). Roots in Boston, branches in planning and parks. In M. Page \& R. F. Mason (Eds.), Giving preservation a history: Essays on the history of historic preservation in the United States (pp. 81-106). Routledge.

Holleran, M., \& Chalana, M. (2006). Historic context and National Register eligibility for Colorado irrigation ditches and canals. CRM: The Journal of Heritage Stewardship, 3(2), 88-93. 
Holleran, M., \& Ibarra-Sevilla, B. (2017). Badlands National Park Centennial Studio. In D. Dietrich-Smith, D. Driaspa, K. Doyle, F. Gale, \& L. Lawliss (Eds.), A century of design in the parks: Preserving the built environment in national and state parks: Santa Fe, New Mexico, June 21-23, 2016 (pp. 347-351). Friends of NCPTT.

Holleran, M., \& Sanders, J. M. (2002). Urban canals in the American West: Irrigation landscapes and city design. In U. Fratino (Ed.), Landscapes of water: History, innovation and sustainable design: Proceedings of the International confeence Monopoli, 26-29 september, 2002 (pp. 269-272). Uniongrafica Corcelli.

Huang, W.-J., Norman, W. C., Hallo, J. C., Mcgehee, N. G., Mcgee, J., \& Goetcheus, C. L. (2014). Serendipity and independent travel. Tourism Recreation Research, 39(2), 169-183.

Hudgins, C. L. (1990). Robert "King" Carter and the landscape of early eighteenth-century Virginia. In W. M. Kelso \& R. Most (Eds.), Earth patterns: Essays in landscape archaeology. University Press of Virginia.

Hudgins, C. L. (1999). Backcountry and lowcountry: Perspectives on Charleston in the context of trans-Atlantic culture, 1700-1850. Historical Archaeology, 33(3), 102-107.

Hudgins, C. L. (2012). The necessary calls of humanity and decency: The archaeology of Robert "King" Carter and the material life of Virginia, 1680-1740. In E. Klingelhofer (Ed.), The archaeology of early Virginia: Essays in honor of Ivor Noel Hume (pp. 173-189). Oxbow.

Hudgins, C. L. (2015). More data, please: Comments on Eric Schweikert's 'Ideologies of consumption and the commodification of goods in 18th-century Virginian and Lowland Scottish rural household.'. Post Medieval Archaeology, 49(1), 175-181.

Hudgins, C. L., \& Leifeste, A. (2017). The documentation course: Beyond drawing. Preservation Education and Research, 9, 47-62.

Hurley, P. T., Grabbatin, B., Goetcheus, C. L., \& Halfacre, A. (2013). Gathering, buying, and growing sweetgrass (Muhlenbergia sericea): Urbanization and social networking in the sweetgrass basket-making industry of lowcountry South Carolina. In R. A. Voeks \& J. Rashford (Eds.), African ethnobotany in the Americas (pp. 153-173). Springer.

Ibarra-Sevilla, B. (2011). Curious acts of geometry: Underlying geometry analysis of two sixteenth century vaults in Mexico. In A. E. Schultz (Ed.), Conference proceedings: The eleventh North American masonry conference. Masonry Society.

Ibarra-Sevilla, B. (2012). Transmission of building technology from Europe to the Americas: Underlying geometry and stereotomy studies of three types of ribbed vaults constructed in Mexico between 1535 \& 1575. In R. Carvais, A. Guillerme, V. Negre, \& J. Sakarovitch (Eds.), Nuts and bolts of construction history: Culture, technology and society, fourth international congress on construction, Paris, 2012 (pp. 393-400). Picard.

Ibarra-Sevilla, B. (2013a). First ribbed vaults of the Americas: Indigenous people skills, construction and crafting processes in the Mixtec region of southern Mexico. Construction History Journal, 28(1), 1-25.

Ibarra-Sevilla, B. (2013b). From fretwork to ribbed vaults. Informes de La Construcción, 65, 6580.

Ibarra-Sevilla, B. (2013c). The hidden face of the vault: Unveiling the expression of the avantgarde through the use of the sphere in Teposcolula's open chapel. Nexus Network Journal, 15(1), 107-125. 
Ibarra-Sevilla, B. (2014). Mixtec stonecutting artistry. Universidad Nacional Autónoma de México.

Ibarra-Sevilla, B. (2015). Unusual conditions = novel solutions: Guastavino's strategies and underlying geometry for the vaults Of irregular plan in New York Municipal Building. In D. Friedman, B. Bowen, T. Leslie, \& J. Ochsendorf (Eds.), Fifth International Construction History Congress, Chicago, 06/2015 (pp. 329-338). The Construction History Society of America.

Ibarra-Sevilla, B. (2018). The city of Oaxaca as World Heritage Site: Challenges to overcome for reaching integrated conservation (K. Penna, J. Tinoco, \& T. Lapa, Eds.; pp. 48-63). Instituto Politécnico do Porto \& $\mathrm{CECl}$.

Jang, J., \& Matero, F. G. (2018). Performance evaluation of commercial nanolime as a consolidant for friable lime-based plaster. APT Bulletin: Journal of Preservation Technology, 57(3), 95-111.

Jerome, P., Weiss, N. R., Risdal-Barnes, M., Crevello, G., \& Chusid, J. M. (2003). Conserving the ruins of a Hellenistic farmhouse in Crimea, Ukraine. APT Bulletin: The Journal of Preservation Technology, 34(2/3), 5-14.

Jessica, K., Matero, F. G., \& Hinchman, J. (2011). Terrestrial laser scanning: Imaging, quantifying, and monitoring microscale surface deterioration of stone at heritage sites. Change Over Time: International Journal of Conservation and the Built Environment, 1(2), 268287,290-291.

Kapp, P. H. (2009). "So, can you revit?" Historic preservation design education and digital media. Preservation Education and Research, 2, 15-26.

Kapp, P. H. (2012). Historic preservation: The foundation of SynergiCity. In P. H. Kapp \& P. J. Armstrong (Eds.), Synergicity: Reinventing the postindustrial city (pp. 28-39). University of Illinois Press.

Kapp, P. H. (2015). Experiencing intangible heritage on the byway: The Mississippi Blues Trail and the Virginia Crooked Road. In M. Robinson \& H. Silverman (Eds.), Encounters with popular pasts: Cultural heritage and popular culture (pp. 49-60). Springer.

Kapp, P. H. (2016). Intangible industrial heritage. In US/ICOMOS (Ed.), With a World Heritage so rich: Lessons from across the globe for US Historic Preservation in its second 50 years (pp. 13-16). US National Committee, International Council on Monuments and Sites.

Kapp, P. H. (2017). The artisan economy and post-industrial regeneration in the US. Journal of Urban Design, 22(4), 477-493.

Kapp, P. H. (2018a). Educating the next generation of preservationists. In R. D. Wagner \& de T. P. Tiller (Eds.), Creating historic preservation in the 21st century (pp. 28-41). Cambridge Scholars Publishing.

Kapp, P. H. (2018b). The university campus in the United States-As a designed work to produce knowledge; and as an artefact of cultural heritage. Built Heritage, 1(2), 49-65.

Kapp, P. H., \& Armstrong, P. J. (Eds.). (2012). Synergicity: Reinventing the postindustrial city. University of Illinois Press.

Kapp, P. H., Bricker, L. W., \& Hoyos, L. (2014). Documentation and design in association: Historic preservation design using social history, advocacy, and drawing in the architectural design studio. In B. L. Stiefel \& J. C. Wells (Eds.), Preservation education: Sharing best practices and finding common ground (pp. 175-191). University Press of New England. 
Kapp, P. H., \& Crumpton, G. (2015). Industry and art: The Jackfield Tile Museum and the John Scott Collection at the Ironbridge Gorge World Heritage Site, Shropshire, England. Journal of the Tiles \& Architectural Ceramics Society, 21, 1-8.

Kapp, P. H., \& Otnes, C. C. (2018). The poppies exhibit: Producing and consuming commemoration of World War I in Britain. In M. Frihammar \& H. Silverman (Eds.), Heritage of death: Landscapes of emotion, memory and practice (pp. 107-122). Routledge.

Kapp, P. H., \& Sanders, T. (2015). The architecture of William Nichols: Building the antebellum South in North Carolina, Alabama, and Mississippi. University Press of Mississippi.

Koolhaas, R., Otero-Pailos, J., \& Carver, J. (2014). Preservation is overtaking us. Columbia Books on Architecture and the City.

Koziol, C. (2007). Ideology and discourse in heritage policy: The importance of defining and framing the extent of "the significant." In N. Silberman \& C. Liuzza (Eds.), Interpreting the past: The future of heritage: Changing visions, attitudes and contexts in the 21st century; selected papers from the third annual ename international colloquium, Monasterium PoortAckere, Ghent, Belgium, 21-24 March 2007 (pp. 21-32). Vlaams Instituut voor het Onroerend Erfgoed.

Koziol, C. (2008). Historic preservation ideology: A critical mapping of contemporary heritage policy discourse. Preservation Education and Research, 1, 41-50.

Koziol, C. (2009). Preservation \& sustainability: The case for "realistic" evidence-based design policy. In H. Rashed-Ali \& S. Roff (Eds.), Proceedings of the 2009 annual research conference of the Architectural Research Centers Consortium: Leadership in architectural research, between academia and the profession (pp. 63-68). University of Texas at San Antonio, College of Architecture.

Koziol, C. (2012). Local heritages of cosmopolitan significance: How the study of World Heritage situates the "ownership" of architecture. In I. Sabouni \& J. Vanegas (Eds.), Local identities global challenges: 2011 ACSA Fall Conference, Houston (pp. 186-192). ACSA Press.

Koziol, C. (2013). How heritage's debate on values fuels its valorization engine: The side effects of controversy from Alois Riegl to Richard Moe. Change Over Time: International Journal of Conservation and the Built Environment, 3(2), 244-257.

Koziol, C. (2014). From international to cosmopolitan: Taking the Venice Charter beyond the "state-party" politics of experts. Change Over Time: International Journal of Conservation and the Built Environment, 4(2), 204-217.

Krishna, A. (2013). Reincarnation of the sacred space: Issues in adaptive use of Hindu temples in India. Forum Journal, 28(1), 37-46.

Krishna, A. (2014). The care and management of historic Hindu temples in India: An examination of preservation policies influenced by the Venice Charter in non-JudeoChristian contexts. Change Over Time: International Journal of Conservation and the Built Environment, 4(2), 358-386.

Krishna, A. (2016). The catalysts for urban conservation in Indian Cities: Economics, politics, and public advocacy in Lucknow. Journal of the American Planning Association, 82(2), 204207. 
Krishna, A. (2017). From alliance to dissonance: Two centuries of local archaeology and conservation in Indian cities. The case of Lucknow, India. In S. Baugher, D. R. Appler, \& W. Moss (Eds.), Urban archaeology, municipal government and local planning: Preserving heritage within the Commonwealth of Nations and the United States (pp. 161-180). Springer International Publishing.

Lafrenz-Samuels, K., \& Rico, T. (Eds.). (2015). Heritage keywords: Rhetoric and redescription in cultural heritage. University Press of Colorado.

Leifeste, A. (2013). Science and technology studies (STS) literature and assumptions in history of building technology courses. Preservation Education and Research, 6, 89-100.

Lim, A. B., Matero, F. G., \& Henry, M. C. (2013). Greening deterioration: Soft capping as preventive conservation for masonry ruin sites. APT Bulletin: Journal of Preservation Technology, 44(2/3), 53-61.

Livi Smith, A. D. (2011). Neither a toddler nor a stick-in-the-mud. Journal of Museum Education, 36(2), 165-170.

Livi Smith, A. D. (2012). The young preservationist: Findings from the first undergraduate historic preservation education symposium. Preservation Education and Research, 5, 87-96.

Livi Smith, A. D. (2014a). Aesthetics and the built environment: No painting or musical piece can compare. In P. P. L. Tinio \& J. K. Smith (Eds.), The Cambridge handbook of the psychology of aesthetics and the arts (pp. 385-419). Cambridge University Press.

Livi Smith, A. D. (2014b). The development of a preservation planning board game. In B. L. Stiefel \& J. C. Wells (Eds.), Preservation education: Sharing best practices and finding common ground (pp. 71-82). University Press of New England.

Livi Smith, A. D. (2017). A practical cultural resource survey tool for preservation. APT Bulletin: The Journal of Preservation Technology, 48(4), 43-50.

Livi Smith, A. D., \& Spencer, M. (2012). A DIY campus preservation plan: Lessons learned at the University of Mary Washington. Planning for Higher Education, 40(2), 5-12.

Marcoux, J. B. (2007). On reconsidering display goods production and circulation in the Moundville Chiefdom. Southeastern Archaeology, 26(2), 232-245.

Marcoux, J. B. (2010a). Pox, empire, shackles, and hides: The Townsend Site, 1670-1715. University of Alabama Press.

Marcoux, J. B. (2010b). The materialization of status and social structure at the Koger's Island Cemetery, Alabama. In L. P. Sullivan \& R. C. Mainfort Jr. (Eds.), Mississippian mortuary practices: Beyond hierarchy and the representationist perspective (pp. 145-173). University Press of Florida.

Marcoux, J. B. (2012a). Glass trade beads from the English colonial period in the Southeast, ca. A.D. 1607 - 1783. Southeastern Archaeology, 31(2), 157-184.

Marcoux, J. B. (2012b). The Cherokees of Tuckaleechee Cove. Museum of Anthropological Archaeology, University of Michigan.

Marcoux, J. B. (2015). A brief description of the Yamasee War. South Carolina Antiquities, 47, 43-49.

Marcoux, J. B., Lansdell, B., \& Poplin, E. C. (2011). Revisiting the Ashley-series: A quantitative analysis of a contact-period household ceramic assemblage in Charleston Harbor. South Carolina Antiquities, 43, 3-20. 
Marcoux, J. B., \& Poplin, E. C. (2012). Defining Wando: A distinct late Woodland manifestation in the Charleston Harbor region. South Carolina Antiquities, 44, 35-65.

Marcoux, J. B., \& Wilson, G. D. (2010). Categories of complexity and the preclusion of practice. In S. Alt (Ed.), Ancient complexities: New perspectives in pre-Columbian North America (pp. 138-152). University of Utah Press.

Mason, R. F. (Ed.). (1999a). Economics and heritage conservation: A meeting organized by the Getty Conservation Institute, December 1998, Getty Center, Los Angeles. Getty Conservation Institute.

Mason, R. F. (1999b). Economics and heritage conservation: Concepts, values, and agendas for research. In R. F. Mason (Ed.), Economics and heritage conservation: A meeting organized by the Getty Conservation Institute, December 1998, Getty Center, Los Angeles (pp. 2-18). Getty Conservation Institute.

Mason, R. F. (2002). Assessing values in conservation planning: Methodological issues and choices. In M. de la Torre (Ed.), Assessing the values of cultural heritage (pp. 5-30). Getty Conservation Institute.

Mason, R. F. (2003). Fixing historic preservation: A constructive critique of "significance." Places, 16(1), 64-71.

Mason, R. F. (2004). Historic preservation, public memory, and the making of modern New York City. In M. Page \& R. F. Mason (Eds.), Giving preservation a history: Essays on the history of historic preservation in the United States (pp. 131-162). Routledge.

Mason, R. F. (2006a). Promoting cultural preservation. In E. L. Birch \& S. M. Wachter (Eds.), Rebuilding urban places after disaster: Lessons from Hurricane Katrina (pp. 259-274). University of Pennsylvania Press.

Mason, R. F. (2006b). Theoretical and practical arguments for values-centered preservation. CRM: The Journal of Heritage Stewardship, 3(2), 21-48.

Mason, R. F. (2008a). Be interested and beware: Joining economic valuation and heritage conservation. International Journal of Heritage Studies, 14(4), 303-318.

Mason, R. F. (2008b). Management for cultural landscape preservation: Insights from Australia. In R. Longstreth (Ed.), Cultural landscapes: Balancing nature and heritage in preservation practice (pp. 180-196). University of Minnesota Press.

Mason, R. F. (2009a). Preservation planning in American cities. Forum Journal, 23(2), 38-44.

Mason, R. F. (2009b). The once and future New York: Historic preservation and the modern city. University of Minnesota Press.

Mason, R. F. (2010). Aesthetic considerations in historic landscape restoration. CRM: The Journal of Heritage Stewardship, 7(2), 30-33.

Mason, R. F. (2012). Broadway as a memory site. In H. Ballon (Ed.), The greatest grid: The master plan of Manhattan, 1811-2011 (pp. 164, 165). Columbia University Press : Museum of the City of New York.

Mason, R. F. (2018). Engaged preservation. Journal of Architectural Education, 72(2), 200-204.

Mason, R. F., \& Avrami, E. (2002). Heritage values and challenges of conservation planning. In J. M. Teutonico \& G. Palumbo (Eds.), Management planning for archaeological sites (pp. 13-26). Getty Conservation Institute. 
Mason, R. F., MacLean, M. G. H., \& de la Torre, M. (2005). Hadrian's Wall World Heritage Site. In M. de la Torre (Ed.), Heritage values in site management: Four case studies (pp. 172216). Getty Conservation Institute.

Mason, R. F., Myers, D., \& de la Torre, M. (2005). Port Arthur Historic Site. In M. de la Torre (Ed.), Heritage values in site management: Four case studies (pp. 116-171). Getty Conservation Institute.

Mason, R. F., Payne, C., \& Sullivan, R. (2014). Wildness and disease and the changing civic landscape: North Brother Island's History. In North Brother Island: The last unknown place in New York City (pp. 16-36). Empire State Editions, an imprint of Fordham University Press.

Matero, F. G. (1983). A rare example of early nineteenth century Trompe L'oeil Decoration: The octagonal reception room at Telfair Mansion, Savannah, Georgia. Bulletin of the Association for Preservation Technology, 15(3), 34-38.

Matero, F. G. (1984). A diagnostic study and treatment evaluation for the cleaning of Perry's Victory and International Peace Memorial. Bulletin of the Association for Preservation Technology, 16(3/4), 39-51.

Matero, F. G. (1993). The conservation of immovable cultural property: Ethical and practical dilemmas. Journal of the American Institute for Conservation, 32(1), 15-21.

Matero, F. G. (1994). Historical approaches to the surface treatment of nineteenth century ironwork: The Rookery. In D. A. Scott, J. Podany, \& B. B. Considine (Eds.), Ancient \& historic metals: Conservation and scientific research: Proceedings of a symposium on ancient and historic metals organized by the J. Paul Getty Museum and the Getty Conservation Institute, November 1991 (pp. 197-228). Getty Conservation Institute.

Matero, F. G. (1995). A programme for the conservation of architectural plasters in earthen ruins in the American Southwest: Fort Union National Monument, New Mexico, USA. Conservation and Management of Archaeological Sites, 1(1), 5-24.

Matero, F. G. (1997). A unity of theory and practice. CRM: Cultural Resource Management, 20(10), 6-8.

Matero, F. G. (1999). Lessons from the Great House: Condition and treatment history as prologue to site conservation and management at Casa Grande Ruins National Monument. Conservation and Management of Archaeological Sites, 3(4), 203-224.

Matero, F. G. (2000a). Beyond compliance: Planning heritage preservation for Native American ancestral sites. CRM: Cultural Resource Management, 23(9), 4-8.

Matero, F. G. (2000b). The conservation of an excavated past. In I. Hodder (Ed.), Towards reflexive method in archaeology: The example at Çatalhöyük (pp. 71-88). McDonald Institute for Archaeological Research, University of Cambridge.

Matero, F. G. (2001a). Colloquium on historic and archaeological mortars: Analysis and characterization; final summarizing discussion. US/ICOMOS Scientific Journal, 3(1), 14.

Matero, F. G. (2001b). On the replication of archaeological and historic mortars. US/ICOMOS Scientific Journal, 3(1), 11.

Matero, F. G. (2003). Managing change: The role of documentation and condition survey at Mesa Verde National Park. Journal of the American Institute for Conservation, 42(1), 3958. 
Matero, F. G. (2004). Exploring conservation strategies for ancestral Puebloan sites: Tsankawi, Bandelier National Monument, New Mexico. Conservation and Management of Archaeological Sites, 6(2), 67-84.

Matero, F. G. (2005). Predicting the past: Situating history within Rome's Orto Botanico. Studies in the History of Gardens \& Designed Landscapes, 25(2), 87-102.

Matero, F. G. (2006a). Loss, compensation and authenticity in architectural conservation. Journal of Architectural Conservation, 12(1), 71-90.

Matero, F. G. (2006b). Making archaeological sites: Conservation as interpretation of an excavated past. In N. Agnew \& J. Bridgland (Eds.), Of the past, for the future: Integrating archaeology and conservation: Proceedings of the conservation theme at the 5th World Archaeological Congress, Washington, D.C., 22-26 June 2003 (pp. 55-63). Getty Conservation Institute.

Matero, F. G. (2007a). All things useful and ornamental: A praxis-based model for conservation education. Built Environment, 33(3), 287-294.

Matero, F. G. (2007b). Loss, compensation and authenticity: The contribution of Cesare Brandi to architectural conservation in America. Future Anterior: Journal of Historic Preservation, History, Theory, and Criticism, 4(1), 45-58.

Matero, F. G. (2010). Making archaeological sites: Experience or interpretation? CRM: The Journal of Heritage Stewardship, 7(2), 51-55.

Matero, F. G. (2011). Placemaking at Coronado State Monument: Edgar Lee Hewett's Feat of Clay. Journal of the West, 50(3), 21-30.

Matero, F. G. (2012). Earthen architecture: Clay feet or a feat of clay. In C. Mileto, F. Vegas, \& V. Cristini (Eds.), Rammed earth conservation: Proceedings of the First International Conference on Rammed Earth Conservation, Restapia 2012, Valencia, Spain, 21-23 June 2012 (pp. 17-20). CRC Press, Taylor \& Francis Group.

Matero, F. G. (2013a). Housing the bell: 150 years of exhibiting an American icon. Change Over Time: International Journal of Conservation and the Built Environment, 3(2), 188-201.

Matero, F. G. (2013b). On time and the modalities of conservation. In P. Hatchfield (Ed.), Ethics \& critical thinking in conservation (pp. 91-110). American Institute for Conservation of Historic and Artistic Works.

Matero, F. G. (2015). Mud brick metaphysics and the preservation of earthen ruins. Conservation and Management of Archaeological Sites, 17(3), 209-223.

Matero, F. G., \& Bass, A. (1995). Design and evaluation of hydraulic lime grouts for the reattachment of lime plasters on earthen walls. Conservation and Management of Archaeological Sites, 1(2), 97-108.

Matero, F. G., \& Cancino, C. (2000). The conservation of earthen archaeological heritage: An assessment of recent trends. In English Heritage, ICOMOS-UK, \& University of Plymouth Centre for Earthen Architecture (Eds.), Terra 2000: 8th international conference on the study and conservation of earthen architecture, Torquay, Devon, UK, May 2000 (pp. 1121). James \& James.

Matero, F. G., del Bono, E., Fong, K. L., Johansen, R., \& Barrow, J. (2000). Condition and treatment history as prologue to site conservation at Casa Grande Ruins National Monument. In English Heritage, ICOMOS-UK, \& University of Plymouth Centre for Earthen Architecture (Eds.), Terra 2000: 8th international conference on the study and 
conservation of earthen architecture, Torquay, Devon, UK, May 2000 (pp. 52-64). James \& James.

Matero, F. G., \& FitzGerald, R. (2007). The fallacies of intent: "Finishing" Frank Lloyd Wright's Guggenheim Museum. APT Bulletin: Journal of Preservation Technology, 38(1), 3-12.

Matero, F. G., Fong, K. L., Del Bono, E., Goodman, M., Kopelson, E., McVey, L., Sloop, J., \& Turton, C. (1998). Archaeological site conservation and management: An appraisal of recent trends. Conservation and Management of Archaeological Sites, 2(3), 129-142.

Matero, F. G., \& Freese, J. E. (1978). Notes on the treatment of oil and grease staining on a masonry surface. Bulletin of the Association for Preservation Technology, 10(2), 132141.

Matero, F. G., Hinchman, J., Tomlin, D., \& Song, K.-B. (2003). A GIS assessment of the Great Hall Ceiling at Drayton Hall, Charleston. APT Bulletin: Journal of Preservation Technology, 34(2/3), 25-35.

Matero, F. G., Matteini, I., \& Vatankhah, R. (2016). Cleaning terra cotta: Recent trends in technical research and practice. APT Bulletin: Journal of Preservation Technology, 47(4), 24-33.

Matero, F. G., \& Peters, J. (2003). Survey methodology for the preservation of historic burial grounds and cemeteries. APT Bulletin: Journal of Preservation Technology, 34(2/3), 3745.

Matero, F. G., \& Siravo, F. (2004). The restoration of the Ayyubid City wall, Cairo: Revitalising a historic metropolis. Umberto Allemandi \& C. For Aga Khan Trust for Culture.

Matero, F. G., \& Snodgrass, J. C. (1992). Understanding regional painting traditions: The New Orleans exterior finishes study. APT Bulletin: Journal of Preservation Technology, 24(1/2), 36-52.

Matero, F. G., \& Tagle, A. A. (1994). Cleaning, iron stain removal, and surface repair of architectural marble and crystalline limestone: The Metropolitan Club. Journal of the American Institute for Conservation, 34(1), 49-68.

Matero, F. G., \& Teutonico, J. M. (1982). The use of architectural sandstone in New York City in the 19th century. Bulletin of the Association for Preservation Technology, 14(2), 11-17.

Matero, F. G., \& Teutonico, J. M. (1996). Approaches to the evaluation of cleaning techniques for unglazed architectural terra cotta. In Architectural ceramics: Their history, manufacture and conservation: A joint symposium of English Heritage and the United Kingdom Institute for Conservation, 22-25 September 1994 (pp. 57-88). James \& James.

Matero, F. G., \& Teutonico, J. M. (Eds.). (2003). Managing change: Sustainable approaches to the conservation of the built environment: 4th Annual US/ICOMOS International Symposium organized by US/ICOMOS, Program in Historic Preservation of the University of Pennsylvania, and the Getty Conservation Institute 6-8 April 2001, Philadelphia, Pennsy/vania. Getty Conservation Institute.

McCullough, R. L. (1995). The landscape of community: A history of communal forests in New England. University Press of New England.

McCullough, R. L. (1998a). Town forests - the Massachusetts plan. In C. H. W. Foster (Ed.), Stepping back to look forward: A history of the Massachusetts forest (pp. 292-318). Harvard Forest, distributed by Harvard University Press. 
McCullough, R. L. (1998b). Vermont: Historic roads and bridges. In P. D. Marriott (Ed.), Saving historic roads: Design and policy guidelines (pp. 154-167). Preservation Press; John Wiley.

McCullough, R. L. (2003). Cultural landscapes and rural historic districts. In T. H. Klein \& L. Sebastian (Eds.), Transportation research circular: National forum on assessing historic significance for transportation programs; May 23-25, 1999, Washington DC (pp. 40-47). Transportation Research Board.

McCullough, R. L. (2010). Bicycle factory remnants. In G. W. Sanderson (Ed.), Cycle history 20: The proceedings of the 20th International Cycle History Conference, Freehold, New Jersey (U.S.A): July 30-August 1, 2009 (pp. 206-218). John Pinkerton Pub Fund.

McCullough, R. L. (2012). A path for kindred spirits: The friendship of Clarence Stein and Benton MacKaye. Columbia College \& The Center for American Places, University of Chicago Press.

McCullough, R. L. (2013). Wheels of fortune: The bicycle boom, trinity cycle, and its keene factory. Historical New Hampshire, 67(1/2), 52-81.

McCullough, R. L. (2015). Old wheelways: Traces of bicycle history on the land. MIT Press.

McCullough, R. L. (2017). Bicycle factory remnants II. In G. W. Sanderson (Ed.), Cycle history 27: Proceedings of the 27th international cycling history conference: North Haven, Connecticut, USA, 2016. ICHC Publications Committee.

McCullough, R. L., Ginger, C., \& Baumflek, M. (2009). Unspoiled Vermont: The nature of conservation in the green mountain state. In C. H. W. Foster (Ed.), Twentieth-century New England land conservation: A heritage of civic engagement (pp. 125-174). Harvard Forest, distributed by Harvard University Press.

McGehee, N. G., Boley, B. B., Hallo, J. C., McGee, J. A., Norman, W., Oh, C.-O., \& Goetcheus, C. L. (2013). Doing sustainability: An application of an inter-disciplinary and mixed-method approach to a regional sustainable tourism project. Journal of Sustainable Tourism, 21(3), 355-375.

McMillan, L. K. (2016). An evaluation of tobacco pipe stem dating formulas. Northeast Historical Archaeology, 45(2016), 18-42.

McMillan, L. K. (2017). "The blood and life of a commonwealth": Illicit trade, identity formation, and imported clay tobacco pipes in the 17th-century Potomac River Valley. In B. J. Heath, E. E. Breen, \& L. A. Lee (Eds.), Material worlds: Archaeology, consumption, and the road to modernity (pp. 35-55). Routledge.

McMillan, L. K., Hatch, D. B., \& Barbara J. Heath. (2014). Dating methods and techniques at the John Hallowes Site (44WM6): A seventeenth-century example. Northeast Historical Archaeology, 43, 18-37.

Melcher, K., Stiefel, B. L., \& Faurest, K. (Eds.). (2017). Community-built: Art, construction, preservation, and place. Routledge.

Miller, D. R., \& Gilmore, R. G., III. (2016). Negotiating tensions: The religious landscape of St. Eustatius, 1636-1795. Journal of Social Archaeology, 16(1), 56-78.

Miller, M. R. (1998). “My part alone”: The world of Rebecca Dickinson, 1787-1802. The New England Quarterly, 71(3), 341-377. 
Miller, M. R. (1999). "And others of our own people": Needlework and women of the rural gentry. In L. Z. Bassett \& J. Larkin (Eds.), What's New England about New England Quilts? (pp. 19-22). Old Sturbridge Village.

Miller, M. R. (2002a). Rebecca Dickinson: A life alone in the early republic. In C. W. Calhoun (Ed.), The human tradition in America from the Colonial Era through Reconstruction (pp. 143-162). Scholarly Resources.

Miller, M. R. (2002b). Tracking the women's movement through the Women's Action Alliance. Journal of Women's History, 14(2), 154-156.

Miller, M. R. (2003a). Dressmaking as a trade for women: Rediscovering a lost art(isanry). In C. Amneus (Ed.), A Separate Sphere: Cincinnati Dressmakers, 1880-1920 (pp. 9-15). Cincinnati Museum of Art.

Miller, M. R. (2003b). Eggs on the sand: Domestic servants and their children in Federal New England. In P. Benes (Ed.), Women's work in New England, 1620-1920: Proceedings of the Dublin seminar for New England Folklife, 2001 (pp. 184-195). Boston University.

Miller, M. R. (2003c). Gender, artisanry, and craft tradition in early New England: The view through the eye of a needle. The William and Mary Quarterly, 60(4), 743-776.

Miller, M. R. (2003d). Gownmaking as a trade for women in eighteenth-century rural New England. Dress: The Journal of the Costume Society of America, 30, 21-37.

Miller, M. R. (2004). Playing to strength: Teaching public history at the turn of the 21st-century. American Studies International, 42(2/3), 174-212.

Miller, M. R. (2005). Labor and liberty in the age of refinement: Gender, class, and the built environment. Perspectives in Vernacular Architecture, 10, 15-31.

Miller, M. R. (2006a). The last mantuamaker: Craft tradition and commercial change in Boston, 1760-1840. Early American Studies: An Interdisciplinary Journal, 4(2), 372-424.

Miller, M. R. (2006b). The needle's eye: Women and work in the age of revolution. University of Massachusetts Press.

Miller, M. R. (2009). Cultivating the past: Essays on the history of Hadley, Massachusetts. University of Massachusetts Press.

Miller, M. R. (2010a). Betsy Ross and the making of America. Henry Holt and Company.

Miller, M. R. (2010b). Mehitable Primus and Addie Brown: Women of color and Hartford's nineteenth-century dressmaking trades. In P. Benes (Ed.), Dressing New England: Clothing, fashion, and identity; Dublic seminar for New England Folklife annual proceedings. Trustees of Historic Deerfield.

Miller, M. R. (2014). Rebecca Dickinson: Independence for a New England woman. Westview Press; Routledge.

Miller, M. R., \& Benes, P. (2001). The accounts of Tryphena Newton Cooke: Work, family and community in Hadley, Massachusetts, 1780-1805. In Textiles in New England II: Four centuries of material life; Proceedings of the Dublin Seminar for New England Folklife (pp. 161-172). Boston University.

Miller, M. R., \& Lanning, A. D. (1994). "Common parlors": Women and the recreation of community identity in Deerfield, Massachusetts, 1870-1920. Gender \& History, 6(3), 435-455. 
Minner, J., Holleran, M., Roberts, A., \& Conrad, J. (2015). Capturing volunteered historical information: Lessons from development of a local government crowdsourcing tool. International Journal of E-Planning Research, 4(1), 19-41.

Minner, J., Roberts, A., Holleran, M., \& Conrad, J. (2018). A smart city remembers its past: Citizens as sensors in survey and mapping of historic places. In C. N. Silva (Ed.), New approaches, methods, and tools in urban e-planning (pp. 95-129). PA IGI Global, Disseminator of Knowledge.

Nesbit, S. (2013). A sharecropper's millennium: Land and the perils of forgiveness in post-Civil War South Carolina. In B. Wright \& Z. W. Dresser (Eds.), Apocalypse and the millennium in the American Civil War era (pp. 175-193). Louisiana State University Press.

Nesbit, S. (2014). Visualizing Emancipation: Mapping the end of slavery in the American Civil War. In J. Zander \& P. J. Mosterman (Eds.), Computation for humanity: Information technology to advance society (pp. 427-435). CRC Press, Taylor \& Francis Group.

Otero-Pailos, J. (1998). Casablanca's régime: The shifting aesthetics of political technologies (1907-1943). Postmodern Culture, 8(2).

Otero-Pailos, J. (2000). Living or leaving the techno-apocalypse: Paul Virilio's critique of technology and its contribution to architecture. Journal of Architectural Education, 54(2), 104-110.

Otero-Pailos, J. (2009). The subjective element in conservation. Nordic Journal of Architectural Research, 21(1), 32-48.

Otero-Pailos, J. (2011). The ambivalence of smoke: Pollution and modern architectural historiography. Grey Room, 44, 90-113.

Otero-Pailos, J. (2015). The ethics of dust: Carthago nova. Architectural Theory Review, 20(1), 115-121.

Otero-Pailos, J. (2016). Preservation art: An interview with Jorge Otero-Pailos. Forum Journal, 30(3), 7-18.

Page, M. (1995). From "miserable dens" to the "marble monster": Historical memory and the design of courthouses in nineteenth-century Philadelphia. The Pennsylvania Magazine of History and Biography, 119(4), 299-343.

Page, M. (1999a). "A vanished city Is restored": Inventing and displaying the past at the Museum of the City of New York. Winterthur Portfolio, 34(1), 49-64.

Page, M. (1999b). The creative destruction of Manhattan, 1900-1940. University of Chicago Press.

Page, M. (1999c). The life and death of a document: Lessons from the strange career of "The Diary of Anne Frank." The Public Historian, 20(1), 87-97.

Page, M. (1999d). "Uses of the axe": Towards a treeless New York. American Studies, 40(1), 4164.

Page, M. (2001). Radical public history in the city. Radical History Review, 79, 114-116.

Page, M. (2005). The heights and depths of urbanism: Fifth Avenue and the creative destruction of Manhattan. In R. Moudry (Ed.), The American skyscraper: Cultural histories (pp. 165184). Cambridge University Press.

Page, M. (2008). Urban design and civil protest. Places, 20(1), 84-87.

Page, M. (Ed.). (2013). Memories of Buenos Aires: Signs of state terrorism in Argentina. University of Massachusetts Press. 
Page, M. (2015). Why we need bad places. Forum Journal, 29(3), 25-33.

Page, M. (2016). Why preservation matters. Yale University Press.

Page, M., \& Conn, S. (1995). The politics of corporate architecture: Skyscrapers in Penn's green country towne. In N. Silberman \& M. Leoni (Eds.), Invisible America: Unearthing our hidden history (pp. 260-261). Henry Holt.

Page, M., \& Mason, R. F. (2004). Introduction: Rethinking the roots of the historic preservation movement. In M. Page \& R. F. Mason (Eds.), Giving preservation a history: Essays on the history of historic preservation in the United States (pp. 3-18). Routledge.

Page, M., \& Miller, M. R. (Eds.). (2016). Bending the future: Fifty ideas for the next fifty years of historic preservation in the United States. University of Massachusetts Press.

Payne, S. R. (2011). Place, gender, ethnicity, and the role of the nation in the lives of Northern Plains women. In R. M. Laegreid \& S. K. Mathews (Eds.), Women on the North American Plains (pp. 68-86). Texas Tech University Press.

Preucel, R. W., \& Matero, F. G. (2008). Placemaking on the northern Rio Grande: A view from Kuaua Pueblo. In P. E. Rubertone (Ed.), Archaeologies of placemaking: Monuments, memories, and engagement in Native North America (pp. 81-99). Left Coast Press.

Reap, J. K. (1979). Legal aspects of historic preservation. The Georgia Historical Quarterly, 63(1), 68-79.

Reap, J. K. (2002). The United States' participation in the World Heritage Convention: A retreat from leadership? In ICOMOS (Ed.), Strategies for the world's cultural heritage: Preservation in a globalised world: Principles, practices and perspectives; proceedings from the 13th ICOMOS General Assembly and Scientific Symposium (pp. 99-103). Comité nacional Español de ICOMOS.

Reap, J. K. (2005). Selected legislative, administrative, and management approaches for protecting the setting of heritage places in the United States. In ICOMOS (Ed.), 15th ICOMOS General Assembly and International Symposium: 'Monuments and sites in their setting-Conserving cultural heritage in changing townscapes and landscapes', 17-21 oct 2005, Xi'an, China. World Pub. Corp.

Reap, J. K. (2006). The United States and the World Heritage Convention. In B. T. Hoffman (Ed.), Art and cultural heritage: Law, policy and practice (pp. 234-238). Cambridge University Press.

Reap, J. K. (2011). Tools and techniques for preserving agricultural landscapes in the United States. In ICOMOS (Ed.), Heritage: A driver of development: Rising to the challenge: Results of the 17th ICOMOS General Assembly symposium organised by ICOMOS France, from November 27 to December 2, 2011 UNESCO House, France (pp. 203-206). ICOMOS France.

Rhodes, J. P. (1997). It finally happened here: The 1968 Riot in Kansas City, Missouri. Missouri Historical Review, 91(3), 295-315.

Rhodes, J. P. (2001). The voice of violence: Performative violence as protest in the Vietnam era. Praeger.

Rhodes, J. P. (2006). The father of Southeast Missouri: Louis Houck and the coming of the railroad. Missouri Historical Review, 100(2), 72-86. 
Rhodes, J. P. (2007). It finally happened here: The 1968 Riot in Kansas City, Missouri. In D. M. Burke \& J. P. Herron (Eds.), Kansas City, America's crossroads: Essays from the Missouri historical review, 1906-2006. State Historical Society of Missouri.

Rhodes, J. P. (2008). Missouri railroad pioneer: The life of Louis Houck. University of Missouri Press.

Rhodes, J. P. (2017). Growing up in a land called Honalee: The Sixties in the lives of American children. University of Missouri Press.

Rhodes, J. P., \& Jeffries, J. L. (2010). Motor City Panthers. In J. L. Jeffries (Ed.), On the ground: The Black Panther Party in communities across America (pp. 125-185). University Press of Mississippi,.

Rico, T. (2008). Negative heritage: The place of conflict in World Heritage. Conservation and Management of Archaeological Sites, 10(4), 344-352.

Rico, T. (2014a). Islamic values as heritage subjects. Material Religion, 10(4), 533-534.

Rico, T. (2014b). Islamophobia and the location of heritage debates in the Arabian Peninsula. In K. Exell \& T. Rico (Eds.), Cultural heritage in the Arabian Peninsula: Debates, discourses and practices (pp. 19-32). Ashgate.

Rico, T. (2014c). The limits of a 'heritage at risk' framework: The construction of post-disaster cultural heritage in Banda Aceh, Indonesia. Journal of Social Archaeology, 14(2), 157176.

Rico, T. (2015). Heritage at risk: The authority and autonomy of a dominant preservation framework. In K. Lafrenz-Samuels \& T. Rico (Eds.), Heritage keywords: Rhetoric and redescription in cultural heritage (pp. 147-162). University Press of Colorado.

Rico, T. (2016a). Constructing destruction: Heritage narratives in the tsunami city. Routledge.

Rico, T. (2016b). Technologies, technocracy, and the promise of "alternative" heritage values $(\mathrm{H}$. Silverman, E. Waterton, \& S. Watson, Eds.; pp. 217-230). Springer.

Rico, T. (2017a). Are trees rooting for us? The heritage of greening in Qatar. CAFE: The Journal of Culture and Agriculture, 39(2), 72-79.

Rico, T. (2017b). Expertise and heritage ethics in the Middle East. International Journal of Middle East Studies, 49(4), 742-746.

Rico, T. (2017c). Heritage studies and Islam: A crisis of representation. Review of Middle East Studies, 51(2), 183-187.

Rico, T. (2017d). Searching for "Islam" in heritage practices and debates in Qatar. Journal of Arabian Studies, 7(2), 211-224.

Rico, T. (2017e). Stakeholder in practice: 'Us', 'them,' and the problem of expertise. In C. Hillerdal, A. Karlström, \& C.-G. Ojala (Eds.), Archaeologies of ' s' $^{\prime}$ and 'them': Debating the politics of ethnicity and indigeneity in archaeology and heritage discourse (pp. 3852). Routledge.

Rico, T. (Ed.). (2017f). The making of Islamic heritage: Muslim pasts and heritage presents. Palgrave Macmillan.

Santoro, L. (2017). Promoting the book of nature: Philadelphia's role in popularizing science for christian citizens in the early republic. Pennsylvania History: A Journal of Mid-Atlantic Studies, 84(1), 30-59.

Semes, S. W. (2001a). Introduction to "the American contribution." In G. Gromort (Ed.), The elements of classical architecture (pp. 19-20). W. W. Norton. 
Semes, S. W. (2001b). The art of composition. In G. Gromort (Ed.), The elements of classical architecture (pp. 16-18). W. W. Norton.

Semes, S. W. (2004). The architecture of the classical interior. W.W. Norton.

Semes, S. W. (2007). "Differentiated" and "compatible": Four strategies for additions to historic settings. Forum Journal, 21(4), 14-25.

Semes, S. W. (2009). The future of the past: A conservation ethic for architecture, urbanism, and historic preservation. Norton \& Company.

Semes, S. W. (2012). Adaptation as a model for new architecture in historic settings: Some observations from Rome. Change Over Time: International Journal of Conservation and the Built Environment, 2(2), 88-105.

Semes, S. W. (2013a). Another Rome: The architecture and urbanism of Armando Brasini. The Classicist, 10, 42-59.

Semes, S. W. (2013b). New buildings in historic settings: Recent conservation experience in England. Forum Journal, 28(1), 13-22.

Semes, S. W. (2014). The classicist at large: Remembering Henry Hope Reed, Jr. (1915-2013). The Classicist, 11, 4-5.

Semes, S. W. (2015a). The city of continuity vs. The city of contrast: Historic preservation, new traditional architecture, and sustainability. In R. Economakis \& L. Krier (Eds.), Durability in construction: Tradition and sustainability in 21st century architecture. Papadakis.

Semes, S. W. (2015b). The classicist at large: Answering the fourth recall to order. The Classicist, $12,4-7$.

Semes, S. W. (2017). New design in old cities: Gustavo Giovannoni on architecture and conservation. Change Over Time: International Journal of Conservation and the Built Environment, 7(2), 212-233.

Semes, S. W. (2018). Gustavo Giovannoni: The complete architect. In G. Amoruso (Ed.), Putting tradition into practice: Heritage, place and design: INTBAU 2017 (pp. 234-245). Springer.

Silver, C. S., Matero, F. G., Wolbers, R. C., \& Snodgrass, J. C. (1993). U.S. Custom House, New York City: Overview of analyses and interpretation of altered architectural finishes. Journal of the American Institute for Conservation, 32(2), 141-152.

Smith, D. A., \& Clements, E. L. (1997). Uneasy money: The high-stakes consequences of lowstakes gambling for Black Hawk, Central City and Cripple Creek, Colorado. Mining History Journal, 4, 55-65.

Smith, M. T., Marcoux, J. B., Gredell, E., \& Waselkov, G. (2017). A seventeenth-century trade gun and associated collection from Pine Island, Alabama. Southeastern Archaeology, 36(1), 62-74.

Spodek, J. C. (2002). Ancient Newari water-supply systems in Nepal's Kathmandu Valley. APT Bulletin: Journal of Preservation Technology, 33(2-3), 65-69.

Spodek, J. C., \& House, S. L. (2017). Synergies of historic housing and sustainable rehab in lowincome neighborhoods. Preservation Education and Research, 9, 95-109.

Spodek, J. C., \& Rosina, E. (2009). Applications of infrared thermography to historic building investigation. Journal of Architectural Conservation, 15(3), 65-81.

Stiefel, B. L. (2009). The Jewish and Crypto-Jewish participation in the age of discovery. Journal of Spanish, Portuguese, and Italian Crypto Jews, 1, 77-94. 
Stiefel, B. L. (2011). The architectural origins of the great early modern urban synagogue. The Leo Baeck Institute Year Book, 56(1), 105-134.

Stiefel, B. L. (2012). The island of one people: An account of the history of the Jews of Jamaica. New West Indian Guide, 86(3), 375-376.

Stiefel, B. L. (2013). A press of many tongues: The globalization of Dutch Jewish literature during the seventeenth and eighteenth centuries. In J. Dewulf, O. Praamstra, \& M. van Kempen (Eds.), Shifting the compass: Pluricontinental connections in Dutch colonial and postcolonial literature (pp. 206-228). Cambridge Scholars Publishing.

Stiefel, B. L. (2014a). Building a house of gathering on our own: Jews, synagogues, architecture, and the building trades in the modern anglophone world. Jewish Historical Studies, 46, 131-153.

Stiefel, B. L. (2014b). Jewish sanctuary in the Atlantic World: A social and architectural history. University of South Carolina Press.

Stiefel, B. L. (2014c). Jews and the renaissance of synagogue architecture, 1450-1730. Pickering \& Chatto Publishers.

Stiefel, B. L. (2014d). The other house museum: Places of worship and the case of synagogues. Collections: A Journal for Museum and Archives Professionals, 10(1), 83-104.

Stiefel, B. L. (2015). "Our museum-Another handsome contribution": A comparative case study of the Charleston Museum during its first formative 150 years. Collections: $A$ Journal for Museum and Archives Professionals, 11(2), 103-114.

Stiefel, B. L. (2016). Urban space and travel on the Jewish Sabbath in the nineteenth century. In C. Bryant, A. Burns, \& P. Readman (Eds.), Walking Histories, 1800-1914 (pp. 219-240). Palgrave Macmillan.

Stiefel, B. L. (2017a). Beyond synagogues and cemeteries: The built environment as an aspect of vernacular Jewish material culture in Charleston, South Carolina. American Jewish History, 101(2), 197-236.

Stiefel, B. L. (2017b). Life at the corner of Swan and Prince William Henry Streets: A snapshot from Bridgetown, Barbados. American Jewish History, 101(2), 241-243.

Stiefel, B. L. (2018a). Beyond names and dates on a tree: How librarians can help explore family heritage and preservation. In C. Smallwood \& Gubnitskaia, Vera (Eds.), Genealogy and the librarian: Perspectives on research, instruction, outreach and management (pp. 156163). McFarland \& Company.

Stiefel, B. L. (2018b). Experimenting with acceptance, Caribbean-style: Jews as aliens in the Anglophone Torrid Zone. In L. H. Roper (Ed.), The Torrid Zone: Caribbean colonization and cultural interaction in the long seventeenth century. University of South Carolina Press.

Stiefel, B. L. (2018c). Rethinking and revaluating UNESCO World Heritage Sites: Lessons experimented within the USA. Journal of Cultural Heritage Management and Sustainable Development, 8(1), 47-61.

Stiefel, B. L., \& Goodwin, G. M. (2009). Three New World Synagogues: Symbols of toleration, pride, and continuity. Jewish Historical Society of British Columbia: The Scribe, 29, 2744.

Stiefel, B. L., \& Leifeste, A. (2018). Sustainable heritage: Merging environmental conservation and historic preservation. Routledge. 
Stiefel, B. L., \& Tesler-Mabé, H. (Eds.). (2016). Neither in dark speeches nor in similitudes: Reflections and refractions between Canadian and American Jews. Wilfrid Laurier University Press.

Stiefel, B. L., \& Wells, J. C. (Eds.). (2014). Preservation education: Sharing best practices and finding common ground. University Press of New England.

Stiles, E. B. (2010). 50 years reconsidered. Forum Journal, 24(4), 15-22.

Sullivan, A. T. (2014). Shotcrete. In T. C. Jester (Ed.), Twentieth-century building materials. History and conservation (pp. 71-76). Getty Publications.

Tomlan, M. A. (1992). Preservation practice comes of age. In A. J. Lee (Ed.), Past meets future: Saving America's historic environments (pp. 73-81). National Trust for Historic Preservation.

Tomlan, M. A. (1994a). Historic preservation education: Alongside architecture in academia. Journal Of Architectural Education, 47(4), 187-196.

Tomlan, M. A. (1994b). Learning to identify and evaluate: The National Register and higher education. CRM: Cultural Resource Management, 17(2), 35.

Tomlan, M. A. (Ed.). (1997). Preservation of what, for whom? : A critical look at historical significance. Goucher College.

Tomlan, M. A. (1998). Preservation education-In service to the community. CRM: Cultural Resource Management, 21(3), 3-4.

Tomlan, M. A. (2010). The early years: Founding the National Council for Preservation Education. Preservation Education and Research, 3, 70-71.

Tomlan, M. A. (2013). Tinged with gold: Hop culture in the United States. University of Georgia Press.

Tomlan, M. A. (2015). Historic preservation: Caring for our expanding legacy. Springer.

Tudor, P. B., Matero, F. G., \& Koestler, R. J. (1990). A case study of the compatibility of biocidal cleaning and consolidation in the restoration of a marble statue. In G. C. Llewellyn \& C. E. O'Rear (Eds.), Biodeterioration research 3: Mycotoxins, biotoxins, wood decay, air quality, cultural properties, general biodeterioration, and degradation; proceedings of the third meeting of the Pan American Biodeterioration Society held August 3-6, 1989, in Washington D.C. (pp. 525-533). Springer \& Plenum Press.

Turdean, C. (2011). Casinos and the digitization of the slot machine, 1950-1989. IEEE Annals of the History of Computing, 33(2), 46-59.

van Den Hurk, J. (2005). The architecture of New Netherland revisited. Perspectives in Vernacular Architecture, 10, 133-152.

van Den Hurk, J. (2006). Origins and survival of Netherlandic building traditions in North America. In M. Dunkeld, J. W. P. Campbell, H. Louw, M. Tutton, B. Addis, \& R. Thorne (Eds.), Proceedings of the second international congress on construction history, vol. 3 (pp. 3191-3209). Short Run Press.

Van West, C. (1983a). Democratic ideology and the Antebellum historian: The case of Henderson Yoakum. Journal of the Early Republic, 3(3), 319-339.

Van West, C. (1983b). Montana's self-confessed elite: The progressive men of Montana. Montana: The Magazine of Western History, 33(4), 36-45.

Van West, C. (1983c). The Democratic and Whig political activists of Middle Tennessee. Tennessee Historical Quarterly, 42(1), 3-17. 
Van West, C. (1985). Coulson and the Clark's Fork Bottom: The economic structure of a prerailroad community, 1874-1881. Montana: The Magazine of Western History, 35, 42-55.

Van West, C. (1986a). Roughing it up the Yellowstone to wonderland: An account of a trip through the Yellowstone Valley in 1879. Montana: The Magazine of Western History, 36(2), 22-35.

Van West, C. (1986b). The Milwaukee road corridor. Montana: The Magazine of Western History, 36(4), 69-71.

Van West, C. (1987a). A landscape of statehood: The Montana state capitol. Montana: The Magazine of Western History, 37(4), 73-75.

Van West, C. (1987b). Acculturation by design: Architectural determinism and the Montana Indian reservations, 1870-1930. Great Plains Quarterly, 7(2), 91-102.

Van West, C. (1987c). Marcus Daly and Montana: One man's imprint on the land. Montana: The Magazine of Western History, 37(1), 60-62.

Van West, C. (1987d). The Soo Line Corridor in northeastern Montana. Montana: The Magazine of Western History, 37(3), 71-73.

Van West, C. (1988a). Continuity and change in Tennessee agriculture: The century farmers of Tennessee. Tennessee Historical Quarterly, 47(3), 162-168.

Van West, C. (1988b). The arch in Helena's nineteenth century architecture. Montana: The Magazine of Western History, 38(2), 77-79.

Van West, C. (1989a). Greenfield Village: A landscape for the present, the past... And of Mr Ford. International Journal of Museum Management and Curatorship, 8(3), 263-277.

Van West, C. (1989b). History and interpretation at the western history museum. The Journal of American Culture, 12(2), 7-11.

Van West, C. (1990). Montana's monuments: History in the making. Montana: The Magazine of Western History, 40(4), 12-25.

Van West, C. (1993). Capitalism on the frontier: Billings and the Yellowstone Valley in the nineteenth century. University of Nebraska Press.

Van West, C. (1994a). Middle Tennessee houses and the plain painter tradition: The work of Fred Swanton in the late Victorian Era. Tennessee Historical Quarterly, 53(1), 56-63.

Van West, C. (1994b). New perspectives on Tennessee medical history. Tennessee Historical Quarterly, 53(3), 152-153.

Van West, C. (1994c). "The best kind of building": The New Deal landscape of the northern Plains, 1933-42. Great Plains Quarterly, 14(2), 129-141.

Van West, C. (1995). A sense of permanency: The commonwealth fund and the Rutherford Hospital and Health Center, 1926-1940. Border States On-Line, 10.

Van West, C. (1996). Building blocks for new economic opportunities: National Register projects at the MTSU Center for Historic Preservation. In P. A. Wells (Ed.), Keys to the marketplace: Problems and issues in cultural and heritage tourism (pp. 1-17). Hisarlik Press.

Van West, C. (1997). Assessing significance and integrity in the National Register Process: Questions of race, class, and gender. In M. A. Tomlan (Ed.), Preservation of what, for whom? : A critical look at historical significance (pp. 109-116). Goucher College.

Van West, C. (1998). Tennessee history: The land, the people, and the culture. University of Tennessee Press. 
Van West, C. (2001). Tennessee's New Deal landscape: A guidebook. University of Tennessee Press.

Van West, C. (2002). Trial and triumph: Essays in Tennessee's African American history. University of Tennessee Press.

Van West, C. (2004a). Architecture. In R. Newby (Ed.), The Rocky Mountain region (pp. 1-27). Greenwood Press.

Van West, C. (2004b). Gospel pearls: Tennesseans and gospel music traditions. In C. Van West \& M. D. Binnicker (Eds.), A history of Tennessee arts: Creating traditions, expanding horizons (pp. 401-414). University of Tennessee Press.

Van West, C. (2004c). Tennessee basketmaking. In C. Van West \& M. D. Binnicker (Eds.), A history of Tennessee arts: Creating traditions, expanding horizons (pp. 175-183). University of Tennessee Press.

Van West, C. (2008a). Creating an irrigator's reclamation service: I.D. "Bud" O’Donnell, civic capitalism, and the U.S. Reclamation Service in the Yellowstone Valley, 1900-1930. In B. A. Storey (Ed.), The Bureau of Reclamation: History essays from the centennial symposium (pp. 315-332). U.S. Department of the Interior, Bureau of Reclamation.

Van West, C. (2008b). Sacred spaces of faith, community, and resistance: Rural African American churches in Jim Crow Tennessee. In A. D. Nieves \& L. M. Alexander (Eds.), We shall independent be: African American place making and the struggle to claim space in the United States (pp. 439-462). University Press of Colorado.

Van West, C. (2016). The Tennessee State Tigerbelles: Cold warriors of the track. In R. A. Swanson \& D. K. Wiggins (Eds.), Separate games: African American sport behind the walls of segregation (pp. 61-74). The University of Arkansas Press.

Van West, C., \& Binnicker, M. D. (Eds.). (2004). A history of Tennessee arts: Creating traditions, expanding horizons. University of Tennessee Press.

VanDerwarker, A. M., Marcoux, J. B., \& Hollenbach, K. D. (2013). Farming and foraging at the crossroads: The consequences of Cherokee and European interaction through the late eighteenth century. American Antiquity, 78(1), 68-88.

Visser, T. D. (1991). How to build a town model. In P. Craighead (Ed.), The hidden design in land use ordinances (pp. 60-68). University of Southern Maine.

Visser, T. D. (1993). A primer on conservation assessments and emergency stabilization for historic farm buildings. APT Bulletin: Journal of Preservation Technology, 25(3/4), 64-69.

Visser, T. D. (1997). Field guide to New England barns and farm buildings. University Press of New England.

Visser, T. D. (2009). The status of professional career openings in historic preservation in the United States. Preservation Education and Research, 2, 73-84.

Visser, T. D. (2012). Porches of North America. University Press of New England.

Vivian, D. J. (1999). South Carolina's architectural ambition: The effort to erect the new state capitol, 1851-1855. The South Carolina Historical Magazine, 100(2), 98-123.

Vivian, D. J. (2005). "A practical architect": Frank P. Milburn and the transformation of architectural practice in the New South, 1890-1925. Winterthur Portfolio, 40(1), 17-45.

Vivian, D. J. (2011). Interpreting the history of the Underground Railroad in Southwest Ohio: The John P. Parker House. Ohio Valley History, 11(3), 65-77. 
Vivian, D. J. (2016a). Contesting neoliberalism: The value of preservation in a globalizing age. In M. Page \& M. R. Miller (Eds.), Bending the future: Fifty ideas for the next fifty years of historic preservation in the United States (pp. 250-253). University of Massachusetts Press.

Vivian, D. J. (2016b). Preserving places: Reflections on the National Historic Preservation Act at fifty from the Public Historian (T. Gaskell, Ed.; pp. 35-37). National Council on Public History.

Vivian, D. J. (2018). A new plantation world: Sporting estates in the South Carolina lowcountry, 1900-1940. Cambridge University Press.

Vivian, D. J., Gilberg, M., \& Listokin, D. (2000). Analyzing the economic impacts of historic preservation. Forum Journal, 14(3), 49-56.

Vlahos, E. (1998). Service learning: Building community; Societal imperatives: Community design. In R. Y. Chow (Ed.), Toward a critical pedagogy for the environment: Proceedings of the 1998 ACSA West Regional Meeting. Dept. of Architecture, University of California.

Vlahos, E. (2006). Preserving ranches: Not only possible, but imperative. CRM: The Journal of Heritage Stewardship, 2(1), 6-12.

Weaver, M. E., \& Matero, F. G. (1997). Conserving buildings: Guide to techniques and materials. John Wiley.

Wells, J. C. (2003). Methods for the preservation of French colonial poteaux en terre (posts-inground) houses. APT Bulletin: The Journal of Preservation Technology, 34(2-3), 55-61.

Wells, J. C. (2006). Possible solutions for the long-term preservation of digital documentation. In D. S. Krotzer (Ed.), Architecture Specialty Group post-prints, the documentation dilemma: Managing conservation data in the 21st century, American Institute for Conservation of Historic and Artistic Works 34th annual meeting, Minneapolis, MN, June 11, 2005 (pp. 38-50). American Institute for the Conservation of Historic \& Artistic Works.

Wells, J. C. (2007a). History of structural hollow clay tile in the United States. Journal of Construction History, 22, 22-46.

Wells, J. C. (2007b). The plurality of truth in culture, context, and heritage: A post-structuralist analysis of urban conservation charters. City and Time, 3(2), 1-14.

Wells, J. C. (2009). Historic preservation: Challenges to collaboration with other disciplines. In M. Chapin, J. Bissell, M. A. L'Heureux, K. D. Moore, M. Rashid, \& K. Spreckelmeyer (Eds.), Proceedings of the Environmental Design Research Association (EDRA) 40 conference: Re: The ethical design of places, Kansas City, MO, May 27 - May 31 (pp. 83-91). Environmental Design Research Association.

Wells, J. C. (2010a). Authenticity in more than one dimension: Reevaluating a core premise of historic preservation. Forum Journal of the National Trust for Historic Preservation, 24(3), 36-40.

Wells, J. C. (2010b). Characterization of the mortars of El Castillo de San Cristóbal. Journal of the American Institute for Conservation, 49(1), 27-44.

Wells, J. C. (2010c). Our history is not false: Perspectives from the revitalisation culture. International Journal of Heritage Studies, 16(6), 417-438.

Wells, J. C. (2012). Using sequential mixed social science methods to define and measure heritage conservation performance. In S. M. Zancheti \& K. Simila (Eds.), 6th international 
seminar on urban conservation: Measuring heritage conservation performance (pp. 165173). CECI \& ICCROM.

Wells, J. C. (2014a). A methodological framework for assessing the "spirit and feeling" of World Heritage properties. In T. R. Gensheimer \& C. L. Guichard (Eds.), World heritage and national registers: Stewardship in perspective (pp. 19-32). Transaction Publishers.

Wells, J. C. (2014b). Social science research methodologies and historic preservation: Broadening the possibilities for a preservation thesis. In B. L. Stiefel \& J. C. Wells (Eds.), Preservation education: Sharing best practices and finding common ground (pp. 245263). University Press of New England.

Wells, J. C. (2015a). In stakeholders we trust: Changing the ontological and epistemological orientation of built heritage assessment through participatory action research. In B. Szmygin (Ed.), How to assess built heritage? Assumptions, methodologies, examples of heritage assessment systems2015 (pp. 215-265). Romualdo Del Bianco Foundatione \& Lublin University of Technology and ICOMOS Committee for Theory and Philosophy of Conservation and Restoration.

Wells, J. C. (2015b). Making a case for historic place conservation based on people's values. Forum Journal of the National Trust for Historic Preservation, 29(3), 44-62.

Wells, J. C. (2015c). The American historic downtown: Characteristics, history and policy. In O. Niglio (Ed.), Historic Towns between East and West (pp. 187-202). Ermes. Servizi editoriali integrati S.r.I.

Wells, J. C. (2016a). Can critical heritage studies provide a workable theory for the future of conservation? In B. Szmygin (Ed.), Heritage in transformation: Cultural heritage protection in XXI century - problems, challenges, predictions (pp. 209-226). ICOMOSPoland, Romualdo Del Bianco Foundatione, Lublin University of Technology.

Wells, J. C. (2016b). Human environment conservation in 2066. In M. Page \& M. R. Miller (Eds.), Bending the future: Fifty ideas for the next fifty years of historic preservation in the United States (pp. 254-257). University of Massachusetts Press.

Wells, J. C. (2017a). Are we "ensnared in the system of heritage" because we do not want to escape? Archaeologies: Journal of the World Archaeological Congress, 13(1), 26-47.

Wells, J. C. (2017b). How are old places different from new places? A psychological investigation of the correlation between patina, spontaneous fantasies, and place attachment. International Journal of Heritage Studies, 23(5), 445-469.

Wells, J. C. (2017c). The Main Street Approach to community design. In K. Melcher, B. L. Stiefel, \& K. Faurest (Eds.), Community-built: Art, construction, preservation, and place (pp. 172189). Routledge.

Wells, J. C. (2018). Challenging the assumption about a direct relationship between historic preservation and architecture in the United States. Frontiers of Architectural Research, 7(4), 455-464.

Wells, J. C., \& Baldwin, E. D. (2012). Historic preservation, significance, and age value: A comparative phenomenology of historic Charleston and the nearby new-urbanist community of I'On. Journal of Environmental Psychology, 32(4), 384-400.

Wells, J. C., Hirsch, A., Grimaldi, B. M., Pooley, K. B., \& Sutherland, E. M. (2016). Latin Americans and heritage values in Allentown's 7th Street corridor. Journal of Architectural and Planning Research, 33(3), 181-198. 
Wells, J. C., \& Lixinski, L. (2016). Heritage values and legal rules: Identification and treatment of the historic environment via an adaptive regulatory framework: Part 1. Journal of Cultural Heritage Management and Sustainable Development, 6(3), 345-364.

Wells, J. C., \& Lixinski, L. (2017). Heritage values and legal rules: Identification and treatment of the historic environment via an adaptive regulatory framework: Part 2. Journal of Cultural Heritage Management and Sustainable Development, 7(3), 345-363.

Wells, J. C., \& Stiefel, B. L. (2014a). An introduction to postsecondary historic environment education. In B. L. Stiefel \& J. C. Wells (Eds.), Preservation education: Sharing best practices and finding common ground (pp. 1-24). University Press of New England.

Wells, J. C., \& Stiefel, B. L. (2014b). Conclusion: Common problems and potential solutions. In B. L. Stiefel \& J. C. Wells (Eds.), Preservation education: Sharing best practices and finding common ground (pp. 283-294). University Press of New England.

West, S., Gaiger, J., \& Otero-Pailos, J. (2010). Heritage values. In S. West (Ed.), Understanding heritage in practice. Manchester University Press.

Weyeneth, R. R., \& Vivian, D. J. (2016). Charting the course: Challenges in public history education, guidance for developing strong public history programs. The Public Historian, 38(3), 25-49.

Whisnant, A. M., \& Miller, M. R. (2016). Pulling from outside, pushing from inside: Imperiled promise and change in the National Park Service. The Public Historian, 38(4), 264-292.

Wunsch, A. V., \& Elliott, J. E. B. (2016). Palazzos of power: Central stations of the Philadelphia Electric Company, 1900-1930. Princeton Architectural Press.

Young, R. A. (2008a). Historic preservation technology. John Wiley and Sons.

Young, R. A. (2008b). Stewardship of the built environment: The emerging synergies from sustainability and historic preservation. In D. Kelbaugh \& K. K. McCullough (Eds.), Writing urbanism: An ASCA publication (pp. 57-60). Routledge.

Young, R. A. (2008c). Striking gold: Historic preservation and LEED. Journal of Green Building, $3(1), 24-43$. 